\title{
Electrical stimulation therapy to promote healing of chronic wounds: a review of reviews
}

\section{Pamela E Houghton}

School of Physical Therapy, Faculty of Health Sciences, Western University, London, ON, Canada
Correspondence: Pamela E Houghton School of Physical Therapy, Western University, Room I588, Elborn College, I20I Western Road, London, ON N6G 2A9, Canada

$\mathrm{Tel}+151966 \mid$ 2III (Extension 88862)

Email phoughto@uwo.ca
This article was published in the following Dove Press journal:

Chronic Wound Care Management and Research

25 January 2017

Number of times this article has been viewed

Purpose: The overall objective of this study is to identify and appraise all of the existing clinical research literature that has evaluated the effect of electrical stimulation therapy (EST) on wound healing outcomes in adults with various types of chronic wounds.

Methods: A systematic and comprehensive search of four electronic databases and gray literature was carried out, and references included in related review articles were checked. Prospective and controlled clinical trials, systematic reviews (SRs), and meta-analyses that assessed the effects of EST on wound healing outcomes were described and appraised. A total PRISMA score was assigned for each included SR based on criteria included in the assessment of multiple systematic reviews (AMSTAR) measurement tool. The percentage of available research that was identified in the SR was also calculated.

Results: Sixty-two clinical research studies involving 2082 patients with pressure ulcers, venous leg ulcers, diabetic foot wounds, and arterial/ischemic wounds, and ulcers of mixed etiology were located. Thirty-three of the studies with 1370 patients compared wound size reduction after EST to a control group. Eighteen reviews that used a systematic approach to identify, select, and evaluate published studies on this topic have yielded conflicting results. Poorer quality SRs with a low total PRISMA score were more likely to yield negative or inconclusive findings. Most of these low-quality SRs had very vague research questions and included less than $50 \%$ of the available literature that was known to exist. Results from 22 well-designed randomized clinical trials and 10 high-quality SRs consistently support that EST can stimulate faster wound size reduction and/or produce a greater number of closed wounds compared to a group of similar patients receiving either standard wound care or sham EST.

Conclusion: Pooled results from well-conducted SRs provide strong support for the use of EST on various types of chronic wounds and pressure ulcers in particular.

Keywords: electrotherapy, pressure ulcer, venous ulcer, diabetic foot ulcer, wound healing, systematic reviews

\section{Introduction}

Electrical stimulation therapy (EST) is an adjunctive therapy designed to deliver low levels of electrical current to tissues in and around the open wound. ${ }^{1}$ There are two or more oppositely charged electrodes placed on the surface of tissues which are composed of a variety of materials and come in different shapes and sizes. Some electrodes are custom designed for wound care, while others have been modified from other clinical uses. Different types of current (direct current, pulsed current) and a range of stimulus parameters (duration, frequency, amplitude) can be selected to deliver electrical energy to the wound; in most instances, the current is unbalanced such as high-voltage 
pulsed current (HVPC), and creates a small charge beneath the electrode.

Electrical energy is used for several clinical indications; for example, electrical activation of nerves and muscles is often employed in physical rehabilitation settings to modulate pain (called transcutaneous electrical nerve stimulation), activate muscles (neuromuscular electrical stimulation [NMES]), and/ or restore function (functional electrical stimulation [FES]). Therefore, EST for wounds is often described by clarifying what it is not. In addition, some devices initially designed for other purposes have been purported to indirectly promote wound closure. ${ }^{2-4}$ Another form of electrotherapy uses high-frequency radio waves $(\mathrm{MHz}$ ) to generate electrical fields within wounded tissues - termed pulsed electromagnetic fields (PEMFs). PEMFs are generated via a single coil electrode that does not have to be placed in contact with the skin and induces the movement of electrically charged molecules (such as electrolytes) in the local region. Since these other forms of electrotherapy are relatively new, clinical and experimental research is scarce, and it is not known if they have similar effects on healing as EST. Unfortunately, few reviews define exactly what is meant by EST, and therefore, different forms are combined. ${ }^{5}$

EST is not a new therapy. Rather, the first report that described that low levels of electricity can be harnessed to stimulate tissues in the wound bed and periulcer skin and promote wound closure was published in $1968 .{ }^{6}$ Since these initial reports, over 60 clinical reports and several hundred experimental studies have investigated the effect of EST on tissue repair processes.

Several best practice guidelines (BPG) have been directed toward the management of common types of wounds such as pressure ulcers, venous leg ulcers (VLUs), and diabetic foot wounds. ${ }^{7-15}$ BPG panels with international and interprofessional representation have reviewed research related to a particular wound type and often assigned EST the highest level of research evidence and strongly support the use of EST in clinical practice. ${ }^{7-12}$ Some BPGs have not recommended EST because of the conflicting results that have emerged from a plethora of recent systematic reviews (SRs). ${ }^{13-16}$

\section{SRs and meta-analyses}

SRs and meta-analyses were introduced relatively recently as a novel research methodology that could help busy clinicians to stay abreast with current research trends. ${ }^{17} \mathrm{An}$ SR is a review of a clearly formulated question that uses systematic and explicit methods to identify, select, and critically appraise relevant research, and to collect and analyze data from the studies that are included in the review. ${ }^{17} \mathrm{An}$ SR is said to be well designed if it addresses a carefully crafted question, employs an objective and comprehensive search of the literature, applies predetermined criteria to select relevant articles, and critically appraises the included studies. When these steps are undertaken, all relevant research published within the dates set out in the review should be included.

Meta-analysis refers to the statistical method used to synthesize results from a series of included studies. ${ }^{18}$ It requires an SR be completed initially to identify relevant and similar studies. If, and only if, the included studies have used a similar outcome measure, then results can be pooled, and an overall treatment effect can be estimated. When the pooled result is in favor of the intervention, it is considered the highest level of research evidence to support implementation of the treatment/intervention into clinical practice. The ability to combine smaller research studies allows researchers and clinicians to consider a body of evidence rather than a single multicenter trial. Correspondingly, meta-analyses and SRs are considered a higher level of evidence than a single large-scale randomized controlled trial (RCT) ${ }^{19}$ Compiling results via meta-analyses is also a practical way to evaluate the efficacy of treatment interventions rather than the more expensive and lengthy multicenter trials that are really only feasible when supported by large industries. These largescale studies that involve hundreds of subjects are seldom feasible, especially for medical devices. The placement of meta-analyses atop the hierarchy of clinical research evidence is dependent on the ability to combine results from several well-conducted clinical trials. Many studies that set out to do a meta-analysis are unable to calculate an overall effect for a particular intervention because similar outcome measures are not consistently employed. Needless to say, these methodologies that synthesize research are only as good as the clinical research that has been previously published in the field. In the wound healing field in particular, most of these reviews have yielded results that are inconclusive and author's call for further research to be conducted. Tricco et al identified a total of 99 SRs that examined interventions/practices that were used to improve healing outcomes in people with various types of chronic wounds. ${ }^{20}$ They concluded that few treatments were consistently effective across all outcomes in the literature..$^{20}$

Various scores have been developed to rate the methodological quality of RCTs designed to test the benefit of clinical interventions. ${ }^{21,22}$ Through this evaluation, clinicians have become aware that flaws can exist in published research and that it is no longer assumed that all clinical trials are created equally. However, the same critical appraisal is not always applied to SRs and meta-analyses. As more SRs are 
published, greater disparities are found, and conflicting results are produced. This can be confusing to clinicians and panel members who are tasked with developing/updating best practice guidelines since they are unsure how to interpret the findings. This is particularly true in the case of the research that has evaluated advanced/adjunctive therapies designed to speed up the closure of chronic wounds.

An international panel of experts was convened in 2007, and using an established consensus process, developed a list of eleven key criteria of SRs and/or meta-analyses. A measurement tool for the "assessment of multiple systematic reviews" 23 (AMSTAR) has been used by others to objectively appraise the quality of published SRs and meta-analyse ${ }^{20}$ - termed herein as the PRISMA score since it reflects "Preferred Reporting Items for Systematic Reviews and Meta-Analysis". ${ }^{17}$

\section{Purpose of this study}

The overall objective of this study is to identify and appraise existing clinical research that has examined the effect of EST on wound healing outcomes in adults with various types of chronic wounds.

Specifically, the review

1. compiles all research studies involving human subjects published before 2016 which have evaluated the effect of EST on wound healing of various chronic wound types;

2. performs a comprehensive literature search to find all the SRs and meta-analyses that have been published to date and evaluate the methodological quality of included reviews using the PRISMA tool, ${ }^{23}$ and

3. critically appraises clinical research that has been published for three common types of wounds (pressure ulcers, VLUs, and diabetic foot wounds).

This study does not address the large amount of work that has been done regarding mechanism of cellular and physiological effects of E-Stim determined using animal or cellular research. A recent review written by $\mathrm{Clark}^{24}$ with a preface by Keith Harding states that "it is a technology that has significant research underpinning it that we should all be aware of". ${ }^{25}$ Readers are referred to a special issue of the journal Advances in Wound Care where several articles reviewed experimental research conducted using animal models and in vitro cell studies and described cellular and physiological mechanisms by which EST stimulates tissue repair and wound closure. ${ }^{26,27}$ In brief, EST has been shown to increase tissue perfusion and oxygenation due to increased local blood supply, reduced venous congestion, and enhanced capillary branching and angiogenesis. EST can also promote inflammation by enhancing white blood cell migration and infiltration into the site of injury (galvanotaxis), increasing the synthesis and release of chemical mediators, and enhancing phagocytosis and natural debridement of foreign and necrotic material. The application of EST to healing wounds stimulates collagen synthesis and organization that promotes deposition of new granulation tissue and creates better wound strength. EST-induced activation of reepithelialization and wound contraction have also been elucidated using both in vivo and in vitro experimental models. ${ }^{27}$ Collectively, this body of research shows that EST influences healing process via several mechanisms that are active in virtually every phase of tissue repair. ${ }^{26,27}$

\section{Methodology}

Five databases (CINHAL, PubMed, Medline, Embase, Scopus) were searched from inception to October 2016 for articles that met predetermined criteria. Table 1 provides a list of specific inclusion and exclusion criteria. An experienced librarian was contacted to develop a search strategy with a comprehensive list of keywords and MeSH terms. Briefly, these English-language articles evaluated the effect of EST on wound healing outcomes in subjects with open wounds of specific or mixed etiology, including but not limited to pressure ulcers, VLUs and/or arterial leg ulcers, or diabetic foot wounds. Articles included all forms of clinical studies involving human subjects such as case studies, uncontrolled prospective and retrospective cohort studies, RCTs and nonRCTs, SRs, and meta-analyses. Clinical studies that were published in only abstract form, written in another language, or did not use the right type of EST were not included (a description of the types of EST addressed in this study is provided in the "Introduction" section). Each included study was carefully checked to confirm that data was unique, and publications involving duplicate data were identified. Reference lists from all articles identified in the extensive search were retrieved, and any additional studies that met inclusion criteria were included. Articles that were published in peerreviewed journals as well as within gray literature sources were included.

To be considered an SR or meta-analysis, a clear description of methods used to search, select, appraise, and analyze the articles needed to be provided. Definitions of SRs and meta-analyses are provided in the "Introduction" section. ${ }^{17,18}$ Reviews lacking these details were considered narrative reviews and summarized in text form. All SRs with or without meta-analysis were evaluated using the PRISMA tool. ${ }^{23}$ Each of the eleven items listed in the document were 
Table I Criteria used to select articles included in this study

\begin{tabular}{|c|c|c|}
\hline Category & Inclusion criteria & Exclusion criteria \\
\hline \multirow[t]{7}{*}{ Population } & Adult & Incisional wounds \\
\hline & Open wounds of any etiology & Skin grafts \\
\hline & Pressure ulcer & \\
\hline & Diabetic foot ulcers & \\
\hline & Venous leg ulcers & \\
\hline & Arterial or ischemic wounds & \\
\hline & Wounds of mixed etiology & \\
\hline \multirow[t]{6}{*}{ Intervention } & Electrical stimulation therapy & Electromagnetic fields or other induced electric fields \\
\hline & At least two surface electrodes placed on or near the wound & Electrical currents used diagnostically \\
\hline & & Use of indwelling or spinal electrodes \\
\hline & & TENS for pain modulation \\
\hline & & NMES for muscle strengthening or endurance \\
\hline & & FES for improvement of functional outcomes \\
\hline \multirow[t]{10}{*}{ Control } & Clinical studies involving human subjects & Languages other than English \\
\hline & Case study & Only abstract available \\
\hline & Case series & Animal or experimental studies \\
\hline & Prospective cohort studies & In vitro cell culture studies \\
\hline & Retrospective cohort studies & Narrative reviews published before 2000 \\
\hline & Nonrandomized controlled trials & Studies with duplicate data \\
\hline & Randomized controlled trials & \\
\hline & Multisite clinical trials & \\
\hline & Systematic reviews & \\
\hline & Meta-analyses & \\
\hline \multirow[t]{6}{*}{ Outcomes } & Wound size reduction & Blood flow \\
\hline & Wound surface area & Wound prevention \\
\hline & Wound appearance using valid outcome measures (PUSH tool) & Wound recurrence \\
\hline & Number of healed wounds & Pain \\
\hline & Time to healing & Quality of life \\
\hline & & Cost analysis \\
\hline
\end{tabular}

Abbreviations: TENS, transcutaneous electrical nerve stimulation; NMES, neuromuscular electrical stimulation; FES, functional electrical stimulation; PUSH, pressure ulcer scale for healing.

assigned one point based on whether the required component was explicitly described in the paper. The number of items present was totaled to yield a "total PRISMA score" out of 11. PRISMA scores of 5 or greater indicate well-conducted SRs and meta-analyses. In addition, key methodological flaws such as including studies with duplicate data and combining different forms of EST were identified.

To determine the comprehensiveness of a review, a value for the percentage of available studies was calculated for each included review and/or meta-analysis. The percentage of available studies was calculated by placing the number of studies about EST which were included in the review over the total number of RCTs that are known to be available in the literature during the time frame of the review. To determine the total number of available studies, the inclusion and exclusion criteria set out within the review were considered. Common exclusion criteria reflected in this calculation were type of wounds or patient group, year of publication, study design, and sample size. Since many reviews excluded clinical trials involving less than 10 subjects or without random allocation to groups, these small studies were seldom included in the total number of available studies. In many instances, the inclusion criteria were not explicitly stated, in which case the authors were given the benefit of doubt.

\section{Results \\ Original clinical research studies: non- randomized and randomized prospective studies}

Research teams from around the world have generated clinical data from a variety of patient demographics, all types of chronic open wounds, and the full spectrum of health care settings.

Table 2 is a summary of controlled clinical trials where E-Stim was used to treat three of the main types of chronic wounds (pressure injuries, ${ }^{28-44}$ venous ulcers and other wounds of the lower extremity, ${ }^{45-53}$ and diabetic and/or ischemic ulcers $\left.{ }^{54}{ }^{60}\right)$. This chart of controlled clinical trials does not include three studies that were found to have the same data presented in another publication - referred to as 
Table 2 Summary of controlled clinical trials that evaluated the effect of EST compared to control treatments on people with pressure ulcers (indicated as "pressure"), VLUs, diabetic foot wounds with or without arterial disease, and ulcers of mixed etiology. For each of the 33 controlled trials, information about the study design, patient group recruited, and EST protocol employed is provided. Calculations made for the average number of treatment hours per week, total number of weeks, and total hours of EST are provided. Results of the between-group analysis are provided, and conclusions drawn by the authors are summarized

\begin{tabular}{|c|c|c|c|c|c|c|c|c|c|}
\hline Author & $\begin{array}{l}\text { Study } \\
\text { design }\end{array}$ & $\mathbf{N}$ & Wound type & Waveform & $\begin{array}{l}\text { Electrode } \\
\text { placement }\end{array}$ & $\begin{array}{l}\text { Hours } \\
\text { per week }\end{array}$ & Weeks & $\begin{array}{l}\text { Total } \\
\text { hours }\end{array}$ & Conclusion \\
\hline \multicolumn{10}{|l|}{ Pressure ulcers } \\
\hline Asbjornsen et al, ${ }^{28}$ Norway & $\mathrm{CT}^{\mathrm{a}}$ & 16 & Pressure & TENS & Hand & 5 & 6 & 30 & No; EST = Con \\
\hline Feedar et al, ${ }^{29}$ USA & $\mathrm{RCT}$ & 47 & Pressure & Pulsed & Wound & 7 & 4 & 28 & Yes; EST > Con \\
\hline Gentzkow et al, ${ }^{30}$ USA & RCT & 37 & Pressure & Pulsed & Wound & 7 & 4 & 28 & Yes; EST > Con \\
\hline Wood et al, ${ }^{31}$ USA & $\mathrm{RCT}$ & 71 & Pressure & LIDC & Periulcer & 0.6 & 8 & 4.8 & Yes; EST > Con \\
\hline Adunsky et al, ${ }^{32}$ Israel & $\mathrm{CT}^{\mathrm{b}}$ & 63 & $\begin{array}{l}\text { Geriatric and } \\
\mathrm{SCl} \text { pressure }\end{array}$ & MENS & Periulcer & 7 & 6 & 42 & $\begin{array}{l}\text { Mixed; D57 EST > Con } \\
\text { DI47 EST = Con }\end{array}$ \\
\hline Ullah, ${ }^{33}$ Belgium & RCT & 60 & Pressure & MENS & $\mathrm{N} / \mathrm{A}$ & 168 & 12 & 2016 & No; EST = Con \\
\hline Franek et al, ${ }^{34}$ Slovenia & RCT & 50 & Pressure & HVPC & Wound & 5 & 6 & 30 & Yes; EST > Con \\
\hline Griffin et al, ${ }^{35}$ USA & $\mathrm{CT}^{\mathrm{a}}$ & 17 & $\mathrm{SCl}$ pressure & HVPC & Wound & 7 & 3 & 20 & Yes; EST > Con \\
\hline $\begin{array}{l}\text { Stefanovska et al, }{ }^{36} \\
\text { Slovenia }\end{array}$ & $\mathrm{CT}^{\mathrm{c}}$ & 50 & $\mathrm{SCl}$ pressure & Pulsed & Periulcer & 14 & 4 & 56 & $\begin{array}{l}\mathrm{BiPc}-\mathrm{EST}>\text { Con } \\
\mathrm{LIDC}-\mathrm{EST}=\text { Con }\end{array}$ \\
\hline Jercinovic et al, ${ }^{37}$ Slovenia & $\mathrm{RCT}$ & 73 & $\mathrm{SCl}$ pressure & Pulsed & Periulcer & 10 & 4 & 16 & $\begin{array}{l}\text { Exponential model; EST > Con } \\
\text { Linear model; EST }=\text { Con }\end{array}$ \\
\hline Karba et al, ${ }^{38}$ Slovenia & $\mathrm{CT}^{\mathrm{a}, \mathrm{c}}$ & 12 & $\mathrm{SCl}$ pressure & Pulsed & Periulcer & 7 & 6.3 & 44.1 & Yes; EST > Con \\
\hline Baker et al,,$^{39}$ USA & RCT & 80 & $\mathrm{SCl}$ pressure & $\begin{array}{l}\text { Pulsed, } \\
\text { MENS }\end{array}$ & Periulcer & 7.5 & $3-6$ & 150 & $\begin{array}{l}\text { No; EST = Con when data was } \\
\text { analyzed in original groups }\end{array}$ \\
\hline Karba et al, ${ }^{40}$ Slovenia & $\mathrm{CT}^{\mathrm{c}}$ & 50 & $\mathrm{SCl}$ pressure & LIDC & Periulcer & 14 & 6.3 & 84 & $\begin{array}{l}\text { Yes; EST > Con positive } \\
\text { polarity }[\mathrm{DC}+/+] \\
\text { No; EST }=\text { Con polarity } \\
\text { alternated [DC }-/+]\end{array}$ \\
\hline $\begin{array}{l}\text { Adegoke and Badmos, }{ }^{41} \\
\text { Nigeria }\end{array}$ & $\mathrm{RCT}^{\mathrm{a}}$ & 7 & $\mathrm{SCl}$ pressure & Pulsed & Wound & 2.25 & 4 & 9 & Yes; EST > Con \\
\hline Barczak et al, ${ }^{42}$ Germany & RCT & 24 & $\mathrm{SCl}$ pressure & Pulsed & Wound & 7 & 12 & 84 & Yes; EST > Con \\
\hline Ahmad, ${ }^{43}$ Saudi Arabia & $\mathrm{RCT}$ & 60 & $\mathrm{SCl}$ pressure & HVPC & Wound & $\begin{array}{l}5.25,7 \\
\text { or } 14\end{array}$ & 5 & 35 & $\begin{array}{l}\text { Yes; EST > Con; } 60 \text { minutes } \\
>45 \text { minutes } \\
60 \text { minutes }=120 \text { minutes }\end{array}$ \\
\hline Houghton et al, ${ }^{44}$ Canada & RCT & 34 & $\mathrm{SCl}$ pressure & HVPC & Wound & 24.5 & 12 & 294 & Yes; EST > Con \\
\hline \multicolumn{10}{|c|}{ VLUs and lower leg ulcers } \\
\hline Ogrin et $\mathrm{al},{ }^{45}$ Australia & $\mathrm{RCT}^{\mathrm{d}}$ & 29 & VLU & TENS & $\begin{array}{l}\text { Limb - } \\
\text { peroneal } \\
\text { nerves }\end{array}$ & 1.16 & 12 & 14 & No; EST = Con \\
\hline Santos et al, ${ }^{46}$ Brazil & $\mathrm{CT}^{\mathrm{a}}$ & 6 & Lower leg ulcers & HVPC & Wound & 1.5 & 8 & 12 & No; EST = Con \\
\hline Gogia et al, ${ }^{47}$ USA & $C T^{\mathrm{a}}$ & 12 & $\begin{array}{l}\text { Lower leg/foot } \\
\text { ulcers }\end{array}$ & HVPC & Wound & 1.67 & 4 & 6.67 & No; EST = Con \\
\hline Houghton et al, ${ }^{48}$ Canada & RCT & 27 & $\begin{array}{l}\text { Leg and foot } \\
\text { ulcers }\end{array}$ & HVPC & Wound & 2.25 & 4 & 9 & Yes; EST > Con \\
\hline Janković and Binić, ${ }^{49}$ Serbia & RCT & 35 & VLU & Pulsed & Periulcer & 3.3 & 3 & 600 & Yes; EST > Con \\
\hline Franek et al,,$^{50}$ Slovenia & $\mathrm{RCT}$ & 79 & VLU & HVPC & Wound & 5 & 6 & 30 & Yes; EST > Con \\
\hline Franek et al, ${ }^{51}$ Slovenia & RCT & 110 & VLU & HVPC & Wound & 5 & 7 & 35 & $\begin{array}{l}\text { Yes; EST > SWC } \\
\text { No; EST = surgery }\end{array}$ \\
\hline Jünger et al, ${ }^{52}$ Germany & $\mathrm{RCT}$ & 39 & VLU & Pulsed & Wound & 7 & 16 & 16 & Yes; EST > Con \\
\hline Katelaris et al, ${ }^{53}$ Australia & $\mathrm{RCT}^{\mathrm{d}}$ & 24 & VLU & MENS & Wound & 168 & 12 & $\begin{array}{l}1104- \\
2047\end{array}$ & $\begin{array}{l}\text { No; EST + proviodine caused } \\
\text { increased wound size }\end{array}$ \\
\hline \multicolumn{10}{|l|}{ Diabetic foot ulcers } \\
\hline Petrofsky et al, ${ }^{54}$ USA & RCT & 20 & $\begin{array}{l}\text { Diabetic foot } \\
\text { ulcers }\end{array}$ & Pulsed & Periulcer & 1.5 & 4 & 6 & Yes; EST > Con \\
\hline Peters et al,$^{55}$ USA & RCT & 40 & $\begin{array}{l}\text { Diabetic foot } \\
\text { ulcers }\end{array}$ & HVPC & Sock & 2.7 & 12 & 32 & Yes; EST > Con \\
\hline Lundeberg et al, ${ }^{56}$ Sweden & RCT & 64 & $\begin{array}{l}\text { Diabetic leg } \\
\text { ulcers and VLUs }\end{array}$ & Pulsed & Periulcer & 4.6 & 12 & 56 & Yes; EST > Con \\
\hline
\end{tabular}


Table 2 (Continued)

\begin{tabular}{|c|c|c|c|c|c|c|c|c|c|}
\hline Author & $\begin{array}{l}\text { Study } \\
\text { design }\end{array}$ & $\mathbf{N}$ & Wound type & Waveform & $\begin{array}{l}\text { Electrode } \\
\text { placement }\end{array}$ & $\begin{array}{l}\text { Hours } \\
\text { per week }\end{array}$ & Weeks & $\begin{array}{l}\text { Total } \\
\text { hours }\end{array}$ & Conclusion \\
\hline Baker et al, ${ }^{57}$ USA & $\mathrm{RCT}$ & 80 & $\begin{array}{l}\text { Diabetic foot } \\
\text { ulcers }\end{array}$ & $\begin{array}{l}\text { Pulsed, } \\
\text { MENS }\end{array}$ & Periulcer & 7.5 & $5-7.5$ & $\begin{array}{l}240- \\
390\end{array}$ & $\begin{array}{l}\text { No; EST = Con when data } \\
\text { was analyzed in original } \\
\text { groups }\end{array}$ \\
\hline Goldman et al, ${ }^{58}$ USA & $\mathrm{CT}^{\mathrm{a}}$ & 8 & $\begin{array}{l}\text { Arterial ischemic } \\
\text { wounds }\end{array}$ & HVPC & Periulcer & 7 & 14 & 98 & Yes; EST > Con \\
\hline \multicolumn{10}{|c|}{ Mixed etiology } \\
\hline Carley and Wainapel, ${ }^{59}$ USA & $\mathrm{RCT}$ & 30 & Geriatric & LIDC & Wound & 20 & 5 & 100 & Yes; EST > Con \\
\hline Kloth and Feedar, ${ }^{60}$ USA & $C T^{a}$ & 16 & Mixed & HVPC & Wound & 3.75 & 7.3 & 27 & Yes; EST > Con \\
\hline
\end{tabular}

Notes: aStudy has less than 10 subjects per group. ' $\mathrm{G}$ reater than $50 \%$ of enrolled subjects did not complete study evaluation period. ${ }^{\mathrm{CPatients}}$ were not randomly assigned to treatment groups. "EST protocol was not optimal to stimulate healing. "Yes; EST > Con" indicates that wound healing outcomes were significantly better than control wounds. "No; EST = Con" indicates that there was no statistically significant difference between EST- and control-treated wounds. "Yes; EST > SWC" indicates wound healing rates were significantly better than standard wound care. "No; EST = surgery" indicates EST produced similar wound healing rates as those receiving surgery. "Pulsed" represents asymmetrical biphasic unbalanced pulsed current.

Abbreviations: EST, electrical stimulation therapy; VLUs, venous leg ulcers; N, number of patients; CT, controlled trial; TENS, transcutaneous electrical nerve stimulation; RCT, randomized controlled trial; Con, control; LIDC, low-intensity direct current; SCl, spinal cord injury; MENS, microcurrent electrical nerve stimulation (<I mA); HVPC, high-voltage pulsed current; BiPc, biphasic pulsed current; DC, direct current; SWC, standard wound care; N/A, not available.

duplicate data. ${ }^{61-63}$ Twenty-two of these 33 studies used a prospective randomized study design where wound healing outcomes were collected systematically using valid outcome measures and well over $80 \%$ of subjects completed the study protocol. ${ }^{29-31,33,34,37,39,42-45,48-57,59}$ Although data from a control group that did not receive EST was included in the report and analyses, eleven studies had key methodological flaws and were labeled "controlled trial" (CT) since they did not use a random allocation method ${ }^{36,38,40}$ or involved fewer than 10 subjects per group. ${ }^{28,35,38,41,46,47,58,60}$ The majority of the controlled studies involved the use of relatively small number of subjects and seldom were the large-scale multicenter trials coordinated by industry. Most controlled clinical trials enrolled a total of 20-50 subjects, and only eight trials had 60 or more subjects in the study. ${ }^{33,37,39,43,50,51,56,57}$ A couple of studies reported only the number of wounds ${ }^{37,64}$ treated, and some included results from multiple wounds from the same patient. $^{33,39,42,49,57,65,66}$

EST was delivered in a variety of ways to tissues surrounding the wound, or directly into the wound bed or both. Most devices used to deliver EST provided pulsed current via small battery-operated devices. Initial research used low levels of direct stimulation called low-intensity direct current. ${ }^{31,40,59} \mathrm{~A}$ few recent reports have employed innovative technologies to deliver very low levels of EST directly to the wound bed through small devices incorporated within the dressing. ${ }^{32,33}$ The remaining included studies, listed in Table 2, which used pulsed current of different designs that delivered short-duration pulses (microsecond duration) at rates between 10 and 100 times per second. Some researchers have claimed that biphasic pulsed current which flows in two directions during the treatment, is less effective than monophasic (or unidirectional current) including HVPC. ${ }^{60}$
Treatment duration ranged between 30 and 75 minutes per session. Ahmad evaluated the effect of increasing the treatment period from 45 to 60 and 120 minutes. ${ }^{43}$ Most treatments were repeated three to seven times per week and based on dressing change schedules. Wound outcomes were evaluated after several weeks of treatment ranging between 3 and 8 weeks. Longer treatment times (lasting 12 weeks) were more commonly used for people with arterial ischemic wounds, ${ }^{58}$ diabetic foot wounds, ${ }^{55,56}$ or spinal cord injury (SCI) ${ }^{42,44}$ or when very low levels of current (microcurrent electrical nerve stimulation, MENS) were used. ${ }^{33}$ This wide range of treatment duration is consistent with studies where EST treatments were given until wound closure and the average time to heal ranged between 3 and 14 weeks. ${ }^{38-40,57,60}$

All but eight studies detected a statistically significant improvement in at least one wound healing outcome after E-Stim treatment compared to a similar control group. ${ }^{28,32,33,39,45-47,53,57}$ Seventeen of 22 well-designed randomized clinical studies found that EST produced faster healing or led to shorter time to closure than controls. Negative findings predominated in studies with small sample sizes (less than 10), ${ }^{28,46,47}$ where very low-intensity EST (MENS) was used, ${ }^{32,33}$ or EST was delivered at a distance from the wound, or where EST protocols were suboptimal ${ }^{45,53}$ Ogrin et $\mathrm{al}^{45}$ performed a double-blinded, randomized, controlled clinical trial; however, the EST treatment was suboptimal since treatments lasted only 5 minutes in duration. Katelaris et $\mathrm{al}^{53}$ also used an EST protocol that was not conducive to healing since they combined EST with proviodine solution, and found that when EST was added to proviodine, wound size actually increased. In addition, there are concerns with two studies performed by Baker et al in which a similar design was used to evaluate the effect of three different EST protocols on individuals with 
diabetic foot ulcers (DFUs $)^{57}$ or people with SCIs. ${ }^{39}$ While a large number of participants were recruited into these studies, it was only after data was modified to include only those with good compliance and by combining MENS-treated individuals with control group that statistical differences were found between groups. Therefore, in this study, the original data analyses were considered for both studies performed by Baker et al, and no effect of EST was recorded.

Several reports document the benefits and safe application of EST on specific cases with very challenging wounds ${ }^{6,64-77}$ and other noncontrolled retrospective ${ }^{78,79}$ and prospective research designs. ${ }^{80-85}$ Two of the original clinical reports are often identified as controlled studies since they included a relatively large number of subjects; however, they compared healing outcomes produced after EST to only six patients with bilateral wounds. ${ }^{86,87}$ Goldman et $\mathrm{al}^{58,79,88,89}$ have produced a number of very compelling reports where EST was used to treat patients with ischemic wounds of the leg and foot often complicated by diabetes. They showed repeatedly that daily treatments with EST progressively increased local tissue perfusion and increases in transcutaneous oxygen pressure measurement (TCPO2) were associated with less pain and better healing outcomes. There are also two larger studies with historical controls which describe improved healing outcomes that can be achieved when EST is applied as part of standard clinical practice. ${ }^{78,90}$

Collectively, the effects of EST on healing have been evaluated in over 2000 subjects and published in a total of 62 articles in peer-reviewed journals since 1968 (Table 3). In 33 of these clinical reports involving 1370 subjects, healing outcomes of an EST-treated group were compared to an appropriate control group. Unfortunately, eleven of the 33 trials were considered of poorer methodological quality. ${ }^{28,35,38,40,41,46,47,50,53,58,60}$

Research that focused on pressure ulcer treatment using EST is most common. A total of 27 clinical reports evaluated the effect of EST on people with pressure ulc ers, ${ }^{28-44,64,67,69-71,74,75,77,79,82,85-87}$ and 17 of these were controlled clinical trials. ${ }^{28-44}$ This extensive search also identified eleven clinical reports $(n=367)$ that have used EST for the treatment of VLUs. Three of these studies ${ }^{46-48}$ included "ulcers of the lower leg" of which the majority were VLUs. Nine of the included studies $(n=361)$ evaluated the effects of EST on leg wounds compared to a control group. ${ }^{45-53}$

Table 3 Summary of clinical research reports published about the effects of EST on wound healing outcomes. Clinical research reports include single case reports, uncontrolled prospective and retrospective cohort studies, and controlled (randomized or not) clinical trials. The number of patients and studies that have been published about pressure ulcers, venous leg ulcers, and diabetic foot wounds of mixed etiology is summarized

\begin{tabular}{|c|c|c|c|c|c|}
\hline & $\begin{array}{l}\text { Pressure } \\
\text { ulcers }\end{array}$ & $\begin{array}{l}\text { Venous } \\
\text { leg ulcers }\end{array}$ & $\begin{array}{l}\text { Diabetic and } \\
\text { arterial wounds }\end{array}$ & $\begin{array}{l}\text { Ulcers of mixed } \\
\text { etiology }\end{array}$ & $\begin{array}{l}\text { Total } \\
\text { number }\end{array}$ \\
\hline \multicolumn{6}{|l|}{ Case reports } \\
\hline Number of studies & 6 & 2 & 5 & 2 & 15 \\
\hline Number of subjects & 13 & 6 & 21 & 2 & 42 \\
\hline \multicolumn{6}{|l|}{ Retrospective analyses } \\
\hline Number of studies & 0 & 0 & 1 & 1 & 2 \\
\hline Number of subjects & 0 & 0 & 24 & 214 & 238 \\
\hline \multicolumn{6}{|l|}{ Prospective cohort studies } \\
\hline Number of studies & 4 & 0 & 2 & 6 & 12 \\
\hline Number of subjects & 117 & 0 & 52 & 263 & 432 \\
\hline \multicolumn{6}{|c|}{ Total number of noncontrolled studies } \\
\hline Number of studies & 10 & 2 & 8 & 9 & 29 \\
\hline Number of subjects & 130 & 6 & 97 & 479 & 712 \\
\hline \multicolumn{6}{|l|}{ Controlled clinical trials } \\
\hline Number of studies & 7 & 2 & I & 1 & 11 \\
\hline Number of subjects & 215 & 18 & 8 & 16 & 257 \\
\hline \multicolumn{6}{|c|}{ Randomized controlled clinical trials } \\
\hline Number of studies & 10 & 7 & 4 & I & 22 \\
\hline Number of subjects & 536 & 343 & 204 & 30 & 1113 \\
\hline \multicolumn{6}{|c|}{ Total number of controlled clinical trials } \\
\hline Number of studies & 17 & 9 & 5 & 2 & 33 \\
\hline Number of subjects & 751 & 361 & 212 & 46 & 1370 \\
\hline Total number of studies & 27 & 11 & 13 & II & 62 \\
\hline Total number of subjects & 881 & 367 & 309 & 525 & 2082 \\
\hline
\end{tabular}

Abbreviation: EST, electrical stimulation therapy. 
While there are 13 studies that focused on wound occurring in people with diabetes, only five were prospective controlled studies with only 212 subjects evaluated. ${ }^{54-58}$ Eleven clinical reports including several uncontrolled prospective cohort studies ${ }^{59,60,65,66,72,74,77,78,80,86-88,91}$ and retrospective analy$\operatorname{ses}^{78}$ showed that the application of EST to a variety of wound types consistently improved healing outcomes. Altogether, this body of literature provides strong support that EST stimulates generic processes of tissue repair and so is effective on many different types of chronic or recalcitrant wounds.

\section{Narrative reviews}

Given the substantive body of literature, there have been several reviews published about either adjunctive therapies in genera ${ }^{92,93}$ or EST for wound healing specifically. ${ }^{24,91,94-100}$ Most of the authors of these narrative reviews formulate an opinion that there is a strong research support for the use of EST to stimulate wound healing and promote wound closure. ${ }^{24,94,96,98,99,101}$ However, some reviewers conclude that research is lacking, conflicting, and/or inconclusive. ${ }^{92,93,97,100}$ Collectively, over 54 clinical reports have been identified by retrieving all the references cited in these reviews. To describe each of these articles in detail is beyond the scope of this study. Readers wishing to find detailed description of all the clinical studies where EST has been used to speed healing or wound closure should refer to comprehensive reviews that addressed all types of wounds. ${ }^{94,97-99,101-103}$

\section{Critical appraisal of SRs and meta-analyses}

Table 4 outlines the details of 18 reviews that have been published in the literature on the effect of EST on wound healing..$^{5,10,14,15,104-116}$ Eight of the reviews completed at least some form of meta-analysis. ${ }^{10,15,104-109}$ Three other reports stated that although a meta-analysis was planned, none was done because of heterogeneity of included studies..$^{14,112,113}$ The first SR published on this topic was produced by Gardner et al in 1999, and impressively, it also included a meta-analysis. ${ }^{109}$

The results of eleven of the 18 included SRs favored the use of EST in the treatment of various types of chronic wou

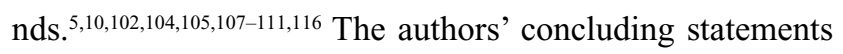
regarding EST use in wound treatments obtained from each review are presented in Table 4. In four reviews, the authors' recommendations suggested that there was no evidence to support routine clinical use of EST for wound therapy..$^{14,12-114}$ Three other reports felt that research was inconclusive..$^{15,106,115}$ It is understandable with the variety of conclusions that clinicians become confused and feel that this area of research has conflicting results. However, if the proportion of available research that was considered and quality of the review is assessed by the PRISMA tool, then a clear trend emerges. All but two ${ }^{15,106}$ of the nine higher quality SRs (with greater than five of eleven items on the PRISMA tool present) found results in favor of EST over standard care, whereas most of the lower quality SRs did not recommend using EST in clinical practice because results were either lacking ${ }^{14,112-114,116}$ or conflicting. ${ }^{115}$

An obvious reason why there is inconsistency across SRs published about the use of EST for treating chronic wounds is that the studies included in each review are quite different. These differences can sometimes be explained by the research question that is defined by each review. Correspondingly, specific inclusion and exclusion criteria are used to define the scope of included studies and to focus on a particular patient population or wound type. To address this issue, the percent of available literature was calculated (Tables 5-7). Even when the inclusion criteria set out by the review were considered, only eleven of 18 published SRs considered the majority $(>50 \%$ ) of clinical trial studies available in the published literature. ${ }^{5,10,102,105-110,115,116}$ In some instances, the inclusion of a relatively low proportion of available studies was explained by the authors' decision to only examine clinical reports published during certain years. Without explanation, two SRs ${ }^{14,112}$ chose not to include any clinical research published before the year 2000 which unfortunately resulted in the exclusion of 18 of possible $33 \mathrm{CTs}$. It is not clear why the review by Health Quality Ontario ${ }^{15}$ described an extensive search strategy and found only $34 \%$ of available articles. However, this low rate of article retrieval does explain why their results were inconclusive. ${ }^{15}$

Another issue in these reviews was that reviewers failed to detect that the same data was presented by authors in two separate publications - called duplicate data. There are three instances where identical data was presented for an EST group - Mulder ${ }^{61}$ and Feedar et $\mathrm{al}^{29}$ in 1991; Trontelj et $\mathrm{al}^{63}$ and Jercinovic et $\mathrm{a}^{37}$ in 1994; and Karba et $\mathrm{al}^{81}$ in 1990 and $\mathrm{Karba}^{80}$ in 1991. While less obvious, given the same time frame and similar treatment groups, it was assumed that similar data was included in the publications by Franek et al in $2005^{62}$ and again in $2006^{51}$ and the retrospective data presented by Stefanovska et al in $1993^{36}$ and Cukjati et al in $2001 .^{78}$ While Lala et al excluded duplicate publications, ${ }^{108}$ this was not picked up by three other reviewers. ${ }^{5,102,106}$ In the present study, data was used only once to calculate total number of published studies and total number of subjects (Table 3). 


\section{Discussion}

The PRISMA tool was used to provide a systematic approach of evaluating the methodological quality of the $\mathrm{SR}^{23}$ (Table 4). A review with a total PRISMA score of 5 or less out of 11 was considered low quality. This approach is consistent with work of other authors..$^{20}$ Admittedly, certain features, such as the comprehensiveness of the search, may be considered more important than other components such as declaring any conflict of interest and providing a list of excluded studies. The ability to include a list of excluded studies is sometimes beyond the control of the authors. Since all but one of these reviews ${ }^{15}$ were published in peerreviewed literature, conflict of interest is often addressed. Publication bias was seldom addressed in these SRs; only one review provided a funnel plot. ${ }^{105}$ This is not surprising since it is a relatively new concept in this field. ${ }^{117}$

In most instances, studies with low total PRISMA scores and also included less than $50 \%$ of available studies published during the time frame were included in the review (Table 4)..$^{14,111-114,116}$ Additionally, five of seven lower quality SRs $^{14,112-116}$ concluded that either EST was not effective in the treatment of chronic wound or results were inconclusive. ${ }^{115}$ SRs that evaluated the effect of EST on all types of chronic wounds were generally well done and included the majority of available research that had been published at the time of the review. ${ }^{102,104-106,109}$ Only one of the eight SRs that focused specifically on the effects of EST or other physical modalities, did not support the use of EST for wound healing. ${ }^{114}$ In the Cochrane review published in 2001, because of different outcomes measured at several time points, the meta-analysis evaluating the pooled effect of EST included only one RCT. ${ }^{106}$ The Cochrane Wounds group tends to make conclusions very conservatively. In fact, only two wound care interventions have been recommended by Cochrane in the past 35 years. The review produced by Koel and Houghton was rated low quality since points were only assigned if the component was clearly described in the text of the paper. ${ }^{104}$ Given that this was an invited review, methodological details were not included. As a coauthor of this meta-analysis, I can state that a very rigorous methodology under the direction of the Cochrane Wounds group was undertaken to select, evaluate, and collate data from included studies.

Ten of 18 reviews that were retrieved addressed pressure ulcers, $5,10,14,15,104,108,110,111,113,114$ and two reviews looked at chronic ulcers occurring in people with diabetes. ${ }^{107,112} \mathrm{~A}$ list of included SRs and meta-analyses is provided in Table 4. Surprisingly, only one SR published to date has focused on VLUs. ${ }^{115}$ Four meta-analyses and one SR evaluated the effect of EST on healing outcomes for all types of chronic wounds. ${ }^{102,104-106,109}$ Within the five reviews that addressed all types of chronic wounds (Table 4), four focused specifically on the effects of EST ${ }^{102,104,105,109}$ and localized more than half of the available literature. Further, all four reviews that focused on the effect of EST but included any type of chronic wound produced results in favor of EST. One meta-analysis published by Barnes et al was particularly well done in that it addressed ten of eleven key items considered essential by PRISMA, and the extensive search identified 20 of possible 26 articles that were published at the time. ${ }^{105}$

A total of ten reviews included in this study evaluated the effect of EST on pressure ulcers (Table 4). The objective of many of these reviews was to examine not just EST, but all pressure ulcer treatments including dressings, novel technologies that addressed underlying causes, and a wide range of adjunctive therapies (skin substitutes, growth factors, and physical agents). Three SRs focused specifically on pressure ulcers in people with $\mathrm{SCI}^{5,108,111}$ reflecting the relatively large number of CTs included those with SCI. ${ }^{32,35-44}$ In some reviews, the authors considered both preventative measures and treatments for pressure ulcers. ${ }^{5,111,114}$ This is a huge body of literature to consider and therefore understandable that most of these expansive reviews did not consider the full body of literature available for EST. Results presented in Table 4 demonstrate that reviews that were not conducted according to the PRISMA guidelines do not consider the majority of studies published about EST, and resulted in conclusions that do not favor EST. In fact, many of these poorly conducted SRs take on expansive topics and end up without recommending any intervention for the management of pressure sores or DFUs. What is most unfortunate is that many of these faulty reviews were developed by national wound care societies and used to direct best practice guidelines for wound care. ${ }^{14,16} \mathrm{An}$ exception to this case was an SR performed by Smith et al in 2013 which was used to inform the Agency for Health Care Policy and Research guidelines. ${ }^{10}$ The scope of this study encompassed all "adjunctive technologies related to pressure ulcer treatment" including dressings, skin grafts, growth factors, and adjunct therapies. The methods addressed most aspects of the PRISMA guidelines, and therefore, the total PRISMA score was 10 of 11 . They concluded that "moderately consistent results from one good and eight fair studies showed that EST improved healing rates". ${ }^{10}$

Only two SRs examined the clinical research published to date regarding the effect of EST on diabetic foot wounds (Table 4). ${ }^{107,112}$ Hinchliffe et al ${ }^{112}$ included very few of available studies, and the total PRISMA scores were 
Table 4 Details about systematic reviews that searched and summarized clinical research that examined the effects of EST on wound healing outcomes in pressure, venous, diabetic, and mixed wound types. Each systematic review was evaluated and assigned a total PRISMA score, and the percentage of available articles that were included in the review was calculated. Conclusions of study authors are provided

\begin{tabular}{|c|c|c|c|c|c|c|c|c|c|c|}
\hline & \multicolumn{5}{|c|}{ Scope of review } & \multicolumn{5}{|c|}{ PRISMA guidelines } \\
\hline & $\begin{array}{l}\text { Publication } \\
\text { year }\end{array}$ & Dates & $\begin{array}{l}\text { Wound } \\
\text { type }\end{array}$ & Treatments & $\begin{array}{l}\text { SR/ } \\
\text { Meta }\end{array}$ & $\begin{array}{l}\text { Clear research } \\
\text { question }\end{array}$ & $\begin{array}{l}\text { Two reviewers } \\
\text { selected }\end{array}$ & $\begin{array}{l}\text { Search } \\
\text { strategy }\end{array}$ & $\begin{array}{l}\text { Gray } \\
\text { literature }\end{array}$ & $\begin{array}{l}\text { List } \\
\text { exclude }\end{array}$ \\
\hline Barnes et al ${ }^{105}$ & 2014 & $\begin{array}{l}\text { October } \\
2013\end{array}$ & ALL & EST & Meta & $Y$ & $Y$ & $Y$ & $\mathrm{~N}$ & $Y$ \\
\hline Smith et a $\left.\right|^{10}$ & 2013 & $1985-2012$ & PrU & All adjuncts & Meta & $Y$ & $Y$ & $Y$ & $Y$ & $Y$ \\
\hline
\end{tabular}

\begin{tabular}{|c|c|c|c|c|c|c|c|c|c|c|}
\hline Cullum et al ${ }^{106}$ & 2001 & $\begin{array}{l}\text { December } \\
1999\end{array}$ & ALL & All treatments & Meta & $Y$ & $Y$ & $Y$ & $Y$ & $Y$ \\
\hline Kwan et al ${ }^{107}$ & 2012 & $|992-20| \mid$ & DFU & All treatments & Meta & N/A & $\mathrm{Y}$ & $Y$ & $\mathrm{~N}$ & $\mathrm{~N}$ \\
\hline Polak et al ${ }^{102}$ & 2014 & 2012 & ALL & HVPC & SR & Y & $\mathrm{N}$ & $Y$ & $\mathrm{~N}$ & $\mathrm{~N}$ \\
\hline $\begin{array}{l}\text { Vélez-Díaz- } \\
\text { Pallarés } \\
\text { et al }{ }^{16}\end{array}$ & 2015 & July 2014 & PrU & $\begin{array}{l}\text { Non- } \\
\text { pharmaceutical } \\
\text { intervention }\end{array}$ & SR & $Y$ & $Y$ & $Y$ & $\mathrm{~N}$ & $\mathrm{~N}$ \\
\hline Lala et al ${ }^{108}$ & 2016 & $\begin{array}{l}\text { January } \\
2014\end{array}$ & PrU-SCI & EST & Meta & $Y$ & $Y$ & $Y$ & $Y$ & $\mathrm{~N}$ \\
\hline Liu et $\mathrm{al}^{5}$ & 2014 & 2013 & PrU-SCl & $\begin{array}{l}\text { EST prevents } \\
\text { and treats }\end{array}$ & SR & Y & $Y$ & $Y$ & $\mathrm{~N}$ & $\mathrm{~N}$ \\
\hline $\begin{array}{l}\text { Health } \\
\text { Quality } \\
\text { Ontario }\end{array}$ & 2009 & $\begin{array}{l}\text { March } \\
2008\end{array}$ & PrU & All treatments & Meta & $Y$ & $\mathrm{~N}$ & $Y$ & $\mathrm{~N}$ & $\mathrm{~N}$ \\
\hline $\begin{array}{l}\text { Gardner } \\
\text { et al }{ }^{109}\end{array}$ & 1999 & NA & ALL & EST & Meta & $Y$ & $\mathrm{~N}$ & $Y$ & $Y$ & $\mathrm{~N}$ \\
\hline $\begin{array}{l}\text { Kawasaki } \\
\text { et al }\end{array}$ & 2013 & June 2013 & PrU & All treatments & $S R$ & $\mathrm{~N}$ & $Y$ & $Y$ & $\mathrm{~N}$ & $\mathrm{~N}$ \\
\hline $\begin{array}{l}\text { Koel and } \\
\text { Houghton }{ }^{104}\end{array}$ & 2014 & NA & ALL & EST & Meta & $\mathrm{N}$ & $Y$ & N/A & $\mathrm{N}$ & $\mathrm{N}$ \\
\hline Regan et al"'I & 2009 & 1980-2007 & PrU-SCl & $\begin{array}{l}\text { ALL prevents } \\
\text { and treats }\end{array}$ & SR & $\mathrm{N}$ & $\mathrm{N}$ & $Y$ & $\mathrm{~N}$ & $\mathrm{~N}$ \\
\hline $\begin{array}{l}\text { Hinchliffe } \\
\text { et al }{ }^{12}\end{array}$ & 2008 & 2006 & DFU & All treatments & SR & N/A & $Y$ & $Y$ & $\mathrm{~N}$ & $\mathrm{~N}$ \\
\hline Reddy et al ${ }^{113}$ & 2008 & $\begin{array}{l}\text { August } \\
2008\end{array}$ & PrU & All treatments & SR & N/A & $\mathrm{N}$ & $Y$ & $\mathrm{~N}$ & $\mathrm{~N}$ \\
\hline
\end{tabular}




\begin{tabular}{|c|c|c|c|c|c|c|c|c|c|}
\hline $\begin{array}{l}\text { Described } \\
\text { inclusion }\end{array}$ & $\begin{array}{l}\text { Method } \\
\text { quality }\end{array}$ & Conclusion & $\begin{array}{l}\text { Meta- } \\
\text { analysis }\end{array}$ & Publication bias & Conflict & Total & $\begin{array}{l}\% \text { of } \\
\text { available } \\
\text { literature }\end{array}$ & $\begin{array}{l}\text { Results } \\
\text { favor } \\
\text { EST }\end{array}$ & Authors' conclusions \\
\hline Y & $Y$ & $Y$ & Y & $Y$ & $Y$ & 10 & 67 & Yes & $\begin{array}{l}\text { EST appears to increase the rate of } \\
\text { ulcer healing and may be superior to } \\
\text { SWC for ulcer treatment }\end{array}$ \\
\hline Y & $Y$ & $Y$ & Y & $N$ & Y & 10 & 50 & Yes & $\begin{array}{l}\text { Moderately consistent results (one } \\
\text { good, eight fair studies) showed } \\
\text { that EST improved healing rates. } \\
\text { Insufficient information about effect } \\
\text { of EST on wound healing }\end{array}$ \\
\hline Y & Y & $Y$ & Y & $\mathrm{N}$ & $Y$ & 9 & 60 & $?$ & $\begin{array}{l}\text { Suggest benefit but insufficient } \\
\text { evidence to draw conclusions }\end{array}$ \\
\hline Y & $Y$ & $Y$ & Y & $Y$ & $Y$ & 8 & 100 & Yes & $\begin{array}{l}\text { Potential benefit of using EPA for } \\
\text { managing DFU. Harmful effects } \\
\text { cannot be ruled out }\end{array}$ \\
\hline Y & $Y$ & Y & N/A & $\mathrm{N}$ & $Y$ & 8 & 90 & Yes & $\begin{array}{l}\text { Efficacy of HVPC promoting VLU } \\
\text { and PrU has been confirmed }\end{array}$ \\
\hline Y & $Y$ & Y & Y & $\mathrm{N}$ & Y & 8 & 75 & Yes & $\begin{array}{l}\text { Data inconclusive, except for low- } \\
\text { quality evidence that supports the } \\
\text { use of electrotherapy }\end{array}$ \\
\hline Y & $Y$ & $Y$ & $Y$ & $N$ & Y & 7 & 89 & Yes & $\begin{array}{l}\text { EST appears to be an effective } \\
\text { adjunctive therapy to accelerate and } \\
\text { increase pressure ulcer closure in } \\
\text { individuals with } \mathrm{SCl}\end{array}$ \\
\hline Y & $Y$ & Y & $\mathrm{N} / \mathrm{A}$ & $\mathrm{N}$ & $Y$ & 7 & 67 & Yes & $\begin{array}{l}\text { A significant effect of EST on } \\
\text { enhancement of PrU is shown in } \\
\text { limited Grade I evidence }\end{array}$ \\
\hline Y & $Y$ & $Y$ & Y & $\mathrm{N}$ & $Y$ & 7 & 36 & $?$ & $\begin{array}{l}\text { No conclusion on efficacy of EST } \\
\text { can be drawn because significant } \\
\text { statistics showed heterogeneity, } \\
\text { small sample sizes, and } \\
\text { methodological flaws of research }\end{array}$ \\
\hline Y & $\mathrm{N}$ & $N$ & $Y$ & $\mathrm{~N}$ & $Y$ & 6 & 67 & Yes & $\begin{array}{l}\text { EST increases rate of chronic wound } \\
\text { healing to } 144 \% \text {. All included studies } \\
\text { showed positive effect of EST }\end{array}$ \\
\hline Y & $Y$ & $Y$ & N/A & $\mathrm{N}$ & $Y$ & 6 & 64 & Yes & $\begin{array}{l}\text { Moderate level of evidence to support } \\
\text { EST use as ancillary treatment } \\
\text { modality for healing pressure ulcers }\end{array}$ \\
\hline Y & $\mathrm{N}$ & $Y$ & $Y$ & $\mathrm{~N}$ & $Y$ & 5 & 58 & Yes & $\begin{array}{l}\text { Adding EST increases PAR by } 26.7 \% \text {. } \\
\text { Unidirectional current is better than } \\
\text { bidirectional current in treating } \\
\text { pressure ulcers }\end{array}$ \\
\hline Y & $Y$ & $Y$ & N/A & $\mathrm{N}$ & $Y$ & 5 & 50 & Yes & $\begin{array}{l}\text { Level I evidence from two RCTs } \\
\text { support use of EST to accelerate } \\
\text { healing rate of SIII and SIV pressure } \\
\text { ulcers when combined with SWC }\end{array}$ \\
\hline Y & $Y$ & $\mathrm{~N} / \mathrm{A}$ & Cannot & $\mathrm{N}$ & $Y$ & 5 & 50 & No & $\begin{array}{l}\text { No data was found to justify the } \\
\text { use of any other topically applied } \\
\text { product or dressing (some hydrogel, } \\
\text { HBO, NPWT) }\end{array}$ \\
\hline Y & $Y$ & $Y$ & Cannot & $N$ & $Y$ & 5 & 46 & No & $\begin{array}{l}\text { There is little evidence to support } \\
\text { use of dressings, routine nutritional } \\
\text { supplementation, or adjunctive } \\
\text { therapies }\end{array}$ \\
\hline
\end{tabular}




\begin{tabular}{|c|c|c|c|c|c|c|c|c|c|c|}
\hline & \multicolumn{5}{|c|}{ Scope of review } & \multicolumn{5}{|c|}{ PRISMA guidelines } \\
\hline & $\begin{array}{l}\text { Publication } \\
\text { year }\end{array}$ & Dates & $\begin{array}{l}\text { Wound } \\
\text { type }\end{array}$ & Treatments & $\begin{array}{l}\text { SR/ } \\
\text { Meta }\end{array}$ & $\begin{array}{l}\text { Clear research } \\
\text { question }\end{array}$ & $\begin{array}{l}\text { Two reviewers } \\
\text { selected }\end{array}$ & $\begin{array}{l}\text { Search } \\
\text { strategy }\end{array}$ & $\begin{array}{l}\text { Gray } \\
\text { literature }\end{array}$ & $\begin{array}{l}\text { List } \\
\text { exclude }\end{array}$ \\
\hline Reddy ${ }^{1 / 4}$ & 2010 & June 2010 & $\operatorname{PrU}$ & All adjuncts & $S R$ & $\mathrm{Y}$ & $N / A$ & $\mathrm{Y}$ & $\mathrm{N} / \mathrm{A}$ & $N$ \\
\hline $\begin{array}{l}\text { Thakral } \\
\text { et al }{ }^{115}\end{array}$ & 2015 & N/A & VLU & $\begin{array}{l}\text { All treatments } \\
\text { included PEMF }\end{array}$ & $S R$ & $Y$ & $\mathrm{~N}$ & $\mathrm{~N}$ & $\mathrm{~N}$ & $Y$ \\
\hline Nicolas et $\mathrm{al}^{14}$ & 2012 & $2000-2010$ & $\operatorname{PrU}$ & $\begin{array}{l}\text { Local medical } \\
\text { devices }\end{array}$ & $S R$ & $\mathrm{~N}$ & $Y$ & $Y$ & $\mathrm{~N}$ & $N$ \\
\hline
\end{tabular}

\begin{abstract}
Notes: N/A - data not available; PrU - pressure ulcers; PrU-SCl - pressure ulcers occurring in people with SCl; ALL - all types of wounds. SR - systematic review was conducted; Meta - both systematic review and meta-analysis were performed; $\mathrm{Y}$ - Yes, the method was conducted; $\mathrm{N}$ - No, there was no mention of that step in the systematic review. Total PRISMA score = sum of II key steps in systematic review and meta-analysis that were performed; $\%$ of available literature $=$ the number of included studies divided by the total number known to be published within the search dates; Results favor EST: Yes - overall treatment effect favors EST or majority of included studies reported improved healing outcomes after EST treatment; Results favor EST: No - no significant differences were detected in EST- vs control-treated wounds. ? indicates results were inconclusive.

Abbreviations: EST, electrical stimulation therapy; SWC, standard wound care; RCT, randomized controlled trial; DFU, diabetic foot ulcer; EPA, electrophysical agent; HVPC, high-voltage pulsed current; SCl, spinal cord injury; PAR, percentage area reduction; HBO, hyperbaric oxygen therapy; NPWT, negative pressure wound therapy; PEMF, pulsed electromagnetic field.
\end{abstract}

correspondingly low. As a result, the International Working Group on the Diabetic Foot guidelines state "no support exists for any intervention used to speed healing of diabetic foot wounds". In another more focused review, Kwan et al ${ }^{107}$ identified all the available literature (100\%) and addressed key methodological issues (total PRISMA score =8). Results were pooled from three RCTs that evaluated the influence of EST on the number of healed DFUs and found a significant odds ratio in favor of EST. ${ }^{107}$ As a result, they concluded that there was potential for using electrotherapies in the management of foot ulcers that occur in people with diabetes. ${ }^{107}$

One review addressed the effects of interventions used in the treatment of venous ulcers. ${ }^{115}$ Thakral et al actually produced two reviews about VLU treatments; ${ }^{95,115}$ however, only one had methods describing an SR process. ${ }^{115}$ Unfortunately, the narrative review included more of the available literature, while the SR cited only two out of a possible seven CTs that had been published at the time of the review. Since there are several well-designed clinical studies that have evaluated the effect of EST on venous ulcers or ulcers of lower limb, future SRs and meta-analyses that pool the results of this body of work are warranted.

As stated in PRISMA guidelines, an extensive search is needed to be confident that the review includes all of the available literature. ${ }^{23}$ These include at least two electronic databases which should be checked by at least two independent reviewers. ${ }^{23}$ In addition, secondary sources such as the reference lists of included studies should also be viewed, and in some instances, hand-searching of relevant journals should be done. ${ }^{23}$ Last but not least, gray literature (not published in peer-reviewed journals) should be included. In all cases, the selection and exclusion of relevant articles should be checked by at least two reviewers acting independently, and discrepancies decided by consensus. ${ }^{23}$ There is a huge number of terms that have been used to name EST for wound healing. This diversity in terminology is expected given that EST has been around for over 50 years and been investigated by researchers located across the world, many of whose first language is not English. Therefore, the search strategy used to find all articles using EST must be developed with by those who have a firm understanding of this modality. Electronic search must include several keywords and MeSH terms that reflect the full range of terms used to name EST. Inclusion and exclusion criteria need to be clearly defined, since electrical currents are used for many other indications including wound prevention. Checking reference lists from included studies and recent narrative reviews is an essential component of any SR on this topic. In addition, any well-conducted SR should include a search of unpublished and gray literature. The challenge in searching for all relevant research related to EST used for wound healing is likely the underlying reason why many published articles are missed and why inconsistent conclusions are drawn from SRs that have addressed this topic. ${ }^{20}$

The most common criticism about clinical studies evaluating EST is that sample sizes are too small. This is certainly the case with clinical studies that have less than 


\begin{tabular}{|c|c|c|c|c|c|c|c|c|c|}
\hline $\begin{array}{l}\text { Described } \\
\text { inclusion }\end{array}$ & $\begin{array}{l}\text { Method } \\
\text { quality }\end{array}$ & Conclusion & $\begin{array}{l}\text { Meta- } \\
\text { analysis }\end{array}$ & Publication bias & Conflict & Total & $\begin{array}{l}\% \text { of } \\
\text { available } \\
\text { literature }\end{array}$ & $\begin{array}{l}\text { Results } \\
\text { favor } \\
\text { EST }\end{array}$ & Authors' conclusions \\
\hline $\mathrm{N}$ & $\mathrm{Y}$ & Y & N/A & $\mathrm{N}$ & $\mathrm{Y}$ & 5 & 25 & No & $\begin{array}{l}\text { We do not know if electrotherapy } \\
\text { improves healing of people with PrU }\end{array}$ \\
\hline Y & $N / A$ & $N / A$ & $N / A$ & $\mathrm{~N}$ & $Y$ & 4 & 77 & $\mathrm{~N} / \mathrm{A}$ & $\begin{array}{l}\text { Utilization of EST in VLU has not } \\
\text { been fully explored. Despite small } \\
\text { sample size, EST showed positive } \\
\text { results and promise as an option for } \\
\text { adjunct therapy }\end{array}$ \\
\hline$N$ & N/A & Y & Cannot & $\mathrm{N}$ & $\mathrm{Y}$ & 4 & 33 & No & $\begin{array}{l}\text { There does not exist evidence } \\
\text { of the efficacy of physical } \\
\text { treatments sufficing to establish } \\
\text { recommendations for their use in } \\
\text { pressure sore treatment }\end{array}$ \\
\hline
\end{tabular}

10 subjects per group. Eight controlled clinical trials in this study contained three to nine subjects per group (Table 2). ${ }^{28,3}$ $5,38,41,46,47,58,60$ Studies that have sample sizes this small lack the power to accurately detect statistically significant differences between groups. Indeed, studies with less than 10 subjects in a group included in this study were equally likely to have either positive ${ }^{35,38,41,58,60}$ or negative $\mathrm{e}^{28,46,47}$ findings. To address this concern, several SRs excluded studies with less than 10 subjects per group. ${ }^{14,104,115}$

According to one study that evaluated the methodological quality of clinical trials, at least 200 subjects should be included in the evaluation; otherwise, the numbers were considered as sparse. ${ }^{114}$ Clearly, none of the included work meets this mark. Given that EST is a medical device without proprietary property, no industry will fund future research involving "larger scale, multicenter clinical trials". In fact, several EST devices previously manufactured are no longer available. ${ }^{29,30,61,96}$

When meta-analyses were first proposed, they were touted as replacing the need for large-scale expensive trials, by combining results from several existing trials in the literature. ${ }^{17,21}$ However, it does require that results are pooled. Of the 18 SRs located (Table 4), only eight did a meta-analysis. Cullum et al used only one RCT in the forest plots, ${ }^{106}$ and three other reviews ${ }^{14,113,114}$ stated that clinical difference was too heterogeneous to be combined in a meta-analysis. Conversely, several reviewers undertook calculations so that data could be pooled. ${ }^{104,105,108,109}$ For example, Gardner et $\mathrm{al}^{109}$ and Lala et $\mathrm{al}^{108}$ calculated weekly healing rates, and
Koel and Houghton ${ }^{104}$ and Barnes et al ${ }^{105}$ extrapolated data to determine percentage area reduction at 4 weeks (PAR4). Combining data from studies that evaluated the effects of EST on a particular type of wound resulted in data that was not heterogeneous $\left(I^{2}<50 \%\right)$.

Another common concern raised by reviewers is that studies were too short and subjects were not followed after closure to determine recurrence. Many reviewers propose that future research should examine the effect of wound care interventions on complete healing or wound closure. The validity of surrogate end points such as wound size reduction after 4-12 weeks has been debated previously. Cardinal et al provided compelling data that suggested that PAR4 was strongly correlated with complete healing. ${ }^{118}$ It is true that only four of the controlled studies for EST examined healing outcomes over 12 weeks or longer. However, several reports reported an average time to healing with EST and control treatments, ${ }^{38-40,57,60}$ and a number of other studies reported the number of ulcers healed in each group. ${ }^{28,29,31,32,35,39,44,48,52,55-57,60}$ What healing outcome is measured and how long the intervention is applied should be dictated by the study question and be reflected in the study design, both of which would be quite different when looking at ulcer healing vs ulcer recurrence. One also needs to recognize that study protocols that evaluate subjects for several months to a year will have high drop-out rates. This was the case in the study by Adunsky et al, where subjects were followed for 147 days; however, the drop-out rate at the final data point was over $50 \% .^{32}$ 
Table 5 Systematic reviews that considered all types of chronic wounds. For each systematic review, the controlled trials that employed EST and were included and analyzed in the reviews are checked

\begin{tabular}{|c|c|c|c|c|c|c|c|}
\hline Author name & $\begin{array}{l}\text { Year of } \\
\text { publication }\end{array}$ & $\begin{array}{l}\text { Gardner } \\
\text { et al }{ }^{109}\end{array}$ & $\begin{array}{l}\text { Cullum } \\
\text { et al }{ }^{106}\end{array}$ & $\begin{array}{l}\text { Health Quality } \\
\text { Ontario }^{15}\end{array}$ & $\begin{array}{l}\text { Koel and } \\
\text { Houghton }{ }^{104}\end{array}$ & $\begin{array}{l}\text { Polak } \\
\text { et al }{ }^{102}\end{array}$ & $\begin{array}{l}\text { Barnes } \\
\text { et al }{ }^{105}\end{array}$ \\
\hline Gault and Gatens ${ }^{86}$ & 1976 & $\checkmark$ & $\checkmark$ & & & & \\
\hline Carley and Wainapel ${ }^{59}$ & 1985 & $\checkmark$ & $\checkmark$ & & $\checkmark$ & & $\checkmark$ \\
\hline Katelaris et $\mathrm{al}^{53}$ & 1987 & $\checkmark$ & & & & & \\
\hline Wolcott et al ${ }^{87}$ & 1968 & $\checkmark$ & $\checkmark$ & & & & \\
\hline Kloth and Feeder ${ }^{60}$ & 1988 & $\checkmark$ & $\checkmark$ & & & $\checkmark$ & $\checkmark$ \\
\hline Asbjornsen et $\mathrm{al}^{28}$ & 1990 & & & & & & $\checkmark$ \\
\hline Feedar et $\mathrm{al}^{29}$ & 1991 & & $\checkmark$ & & $\checkmark$ & & $\checkmark$ \\
\hline Gentzkow et a $\left.\right|^{30}$ & 1991 & $\checkmark$ & $\checkmark$ & $\checkmark$ & & & $\checkmark$ \\
\hline Griffin et al ${ }^{35}$ & 1991 & $\checkmark$ & $\checkmark$ & $\checkmark$ & & $\checkmark$ & $\checkmark$ \\
\hline Mulder et $\mathbf{a l}^{61}$ & 1991 & & $\checkmark$ & & & & \\
\hline Gogia et $\mathrm{a}^{47}$ & 1992 & $\checkmark$ & & & & & \\
\hline Lundeberg et al ${ }^{56}$ & 1992 & $\checkmark$ & $\checkmark$ & & & & $\checkmark$ \\
\hline Stefanovska et $a^{36}$ & 1993 & & & & & & \\
\hline Wood et $\mathrm{al}^{31}$ & 1993 & $\checkmark$ & $\checkmark$ & $\checkmark$ & $\checkmark$ & & $\checkmark$ \\
\hline Jercinovic et $\mathrm{al}^{37}$ & 1994 & & & & & & $\checkmark$ \\
\hline Trontelj et $\mathbf{a}^{63}$ & 1994 & & & & & & \\
\hline Karba et $\mathrm{al}^{38}$ & 1995 & & & & & & \\
\hline Baker et $\mathrm{a}^{39}$ & 1996 & $\checkmark$ & & & $\checkmark$ & & $\checkmark$ \\
\hline Karba et $\mathrm{al}^{40}$ & 1997 & & & & & & \\
\hline Baker et al ${ }^{57}$ & 1997 & & & & $\checkmark$ & & $\checkmark$ \\
\hline Franek et al ${ }^{50}$ & 2000 & & & & & $\checkmark$ & \\
\hline Adegoke and Badmos ${ }^{41}$ & 2001 & & & & & $\checkmark$ & $\checkmark$ \\
\hline Barczak et $\mathrm{al}^{42}$ & 2001 & & & & $\checkmark$ & & \\
\hline Peters et $\mathrm{a}^{55}$ & 2001 & & & & $\checkmark$ & $\checkmark$ & $\checkmark$ \\
\hline Houghton et a $\left.\right|^{48}$ & 2003 & & & & $\checkmark$ & $\checkmark$ & $\checkmark$ \\
\hline Goldman et $\mathrm{al}^{58}$ & 2004 & & & & & & $\checkmark$ \\
\hline Adunsky et $\mathrm{al}^{32}$ & 2005 & & & $\checkmark$ & & & $\checkmark$ \\
\hline Franek et $\mathrm{al}^{62}$ & 2005 & & & & & $\checkmark$ & \\
\hline Franek et $\mathrm{a}^{51}$ & 2006 & & & & $\checkmark$ & $\checkmark$ & \\
\hline Ullah ${ }^{33}$ & 2007 & & & & & & \\
\hline $\mathrm{Ahmad}^{43}$ & 2008 & & & & $\checkmark$ & & $\checkmark$ \\
\hline Janković and Binić ${ }^{49}$ & 2008 & & & & $\checkmark$ & & $\checkmark$ \\
\hline Jünger et $\mathrm{al}^{52}$ & 2008 & & & & $\checkmark$ & & $\checkmark$ \\
\hline Ogrin et $\mathrm{a}^{45}$ & 2009 & & & & & & $\checkmark$ \\
\hline Santos et $\mathrm{al}^{46}$ & 2009 & & & & & & \\
\hline Houghton et $\mathrm{a}^{44}$ & 2010 & & & & $\checkmark$ & $\checkmark$ & $\checkmark$ \\
\hline Petrofsky et al ${ }^{54}$ & 2010 & & & & $\checkmark$ & & \\
\hline Franek et $\mathrm{al}^{34}$ & 2012 & & & & $\checkmark$ & $\checkmark$ & \\
\hline Count & 39 & 11 & 10 & 4 & 15 & 10 & 21 \\
\hline
\end{tabular}

Note: Bold text indicates duplicate data was included.

Abbreviation: EST, electrical stimulation therapy.

Some reviewers indicate that there are serious methodological flaws within the published literature, while others assign this area of research a level 1 evdience. ${ }^{10,110,111}$ Common flaws identified in study designs included a lack of blinding, no description of randomization or concealment methods, and/or no intention-to-treat (ITT) analysis. With regard to concerns about the randomization process, this was likely due to poor reporting rather poor methodology, since many of the clinical trials were published well before the assessment tools evaluating RCT designs were developed. Similarly, ITT analysis is a relatively new concept that only more recent studies have included. Many reviewers identify that research evaluating the effect of EST has inadequate blinding of participants and researchers. Given the nature of EST, this criticism seems unreasonable. EST protocols described in the literature would result in a sensation under the active electrode or produce a visible muscle twitch, both of which make deriving a placebo or sham treatment virtually 
Table 6 Systematic reviews that considered pressure ulcers. For each systematic review, the controlled trials that employed EST and were included and analyzed in the reviews are checked

\begin{tabular}{|c|c|c|c|c|c|c|c|c|c|c|c|}
\hline \multirow[t]{2}{*}{ Author name } & \multirow[t]{2}{*}{$\begin{array}{l}\text { Year of } \\
\text { publication }\end{array}$} & & \multirow[t]{2}{*}{$\begin{array}{l}\text { Reddy } \\
\text { et al }{ }^{1 / 3}\end{array}$} & \multirow[t]{2}{*}{ Reddy ${ }^{1 / 4}$} & \multirow[t]{2}{*}{$\begin{array}{l}\text { Nicolas } \\
\text { et } \mathrm{al}^{1 / 4}\end{array}$} & \multirow[t]{2}{*}{$\begin{array}{l}\text { Kawasaki } \\
\text { et al }{ }^{110}\end{array}$} & \multirow[t]{2}{*}{$\begin{array}{l}\text { Smith } \\
\text { et } \mathrm{al}^{10}\end{array}$} & \multirow{2}{*}{$\begin{array}{l}\text { Vélez-Díaz- } \\
\text { Pallarés } \\
\text { et al }{ }^{116} \\
\text { Elderly }\end{array}$} & \multirow{2}{*}{$\begin{array}{l}\text { Regan } \\
\text { et al"'" } \\
\mathrm{SCl} \\
\end{array}$} & \multirow{2}{*}{$\begin{array}{l}\begin{array}{l}\text { Liu } \\
\text { et } \text { al }^{5}\end{array} \\
\text { SCI }\end{array}$} & \multirow{2}{*}{$\begin{array}{l}\begin{array}{l}\text { Lala } \\
\text { et al }\end{array} \\
\text { SCI }\end{array}$} \\
\hline & & & & & & & & & & & \\
\hline Kloth and Feeder ${ }^{60}$ & 1988 & & $\checkmark$ & & & & $\checkmark$ & $\checkmark$ & & & \\
\hline Asbjornsen et $\mathrm{al}^{28}$ & 1990 & & $\checkmark$ & & & & & $\checkmark$ & & & \\
\hline Gentzkow et al ${ }^{30}$ & 1991 & & & $\checkmark$ & & & $\checkmark$ & $\checkmark$ & & & \\
\hline Griffin et al ${ }^{35}$ & 1991 & $\mathrm{SCl}$ & $\checkmark$ & & & $\checkmark$ & & & $\checkmark$ & $\checkmark$ & $\checkmark$ \\
\hline Feedar et $\mathrm{al}^{29}$ & 1991 & & & & & & & $\checkmark$ & & & \\
\hline Mulder et $\mathrm{al}^{61}$ & 1991 & & & & & & & $\checkmark$ & & & \\
\hline Stefanovska et a ${ }^{36}$ & 1993 & $\mathrm{SCl}$ & & & & $\checkmark$ & & & $\checkmark$ & $\checkmark$ & $\checkmark$ \\
\hline Wood et $\mathrm{al}^{31}$ & 1993 & & $\checkmark$ & & & $\checkmark$ & $\checkmark$ & $\checkmark$ & & & \\
\hline Jercinovic et $\mathrm{al}^{37}$ & 1994 & $\mathrm{SCl}$ & & & & & & & & $\checkmark$ & $\checkmark$ \\
\hline Trontelj et $\mathbf{a l}^{63}$ & 1994 & & & & & & & & & $\checkmark$ & \\
\hline Karba et $\mathrm{al}^{38}$ & 1995 & $\mathrm{SCl}$ & & & & & & & & & $\checkmark$ \\
\hline Baker et a ${ }^{39}$ & 1996 & $\mathrm{SCl}$ & & & & $\checkmark$ & & & $\checkmark$ & $\checkmark$ & $\checkmark$ \\
\hline Karba et al ${ }^{40}$ & 1997 & $\mathrm{SCl}$ & & & & $\checkmark$ & & & & $\checkmark$ & $\checkmark$ \\
\hline Adegoke and Badmos ${ }^{41}$ & 2001 & $\mathrm{SCl}$ & $\checkmark$ & & & & & & $\checkmark$ & $\checkmark$ & \\
\hline Barczak et al ${ }^{42}$ & 2001 & $\mathrm{SCl}$ & & & & & & & & & $\checkmark$ \\
\hline Adunsky et $\mathrm{al}^{32}$ & 2005 & & $\checkmark$ & $\checkmark$ & $\checkmark$ & $\checkmark$ & $\checkmark$ & $\checkmark$ & & & \\
\hline Ullah et $\mathrm{al}^{33}$ & 2007 & & & & $\checkmark$ & & & & & & \\
\hline $\mathrm{Ahmad}^{43}$ & 2008 & $\mathrm{SCl}$ & & & $\checkmark$ & $\checkmark$ & & & & & \\
\hline Houghton et a ${ }^{44}$ & 2010 & $\mathrm{SCl}$ & & $\checkmark$ & $\checkmark$ & $\checkmark$ & $\checkmark$ & & & $\checkmark$ & $\checkmark$ \\
\hline Franek et $\mathrm{al}^{34}$ & 2012 & & & & & $\checkmark$ & & & & & \\
\hline Count & 20 & & 6 & 3 & 4 & 9 & 5 & 7 & 4 & 8 & 8 \\
\hline
\end{tabular}

Note: Bold text indicates duplicate data was included.

Abbreviations: EST, electrical stimulation therapy; SCI, spinal cord injury.

Table 7 Systematic reviews that considered leg and foot wounds. For each systematic review, the controlled trials that employed EST and were included and analyzed in the reviews are checked

\begin{tabular}{|c|c|c|c|c|}
\hline \multirow[t]{2}{*}{ Author name } & \multirow{2}{*}{$\begin{array}{l}\text { Year of } \\
\text { publication }\end{array}$} & \multirow{2}{*}{$\begin{array}{l}\text { Hinchliffe et al }{ }^{1 / 2} \\
\text { DFU }\end{array}$} & \multirow{2}{*}{$\begin{array}{l}\text { Kwan et al }{ }^{107} \\
\text { DFU }\end{array}$} & \multirow{2}{*}{$\begin{array}{l}\text { Thakral et al }{ }^{1 / 5} \\
\text { VLU }\end{array}$} \\
\hline & & & & \\
\hline \multicolumn{5}{|l|}{ VLU } \\
\hline Katelaris et $\mathrm{al}^{53}$ & 1987 & & & \\
\hline Gogia et $\mathrm{al}^{47}$ & 1992 & & & \\
\hline Lundeberg et $\mathrm{a}^{56, a}$ & 1992 & & & $\checkmark$ \\
\hline Franek et $\mathrm{al}^{50}$ & 2000 & & & $\checkmark$ \\
\hline Houghton et al ${ }^{48}$ & 2003 & & & \\
\hline Franek et $\mathrm{a}^{62, \mathrm{c}}$ & 2005 & & & \\
\hline Franek et $\mathrm{a}^{51}$ & 2006 & & & \\
\hline Janković and Binić ${ }^{49}$ & 2008 & & & \\
\hline Jünger et $\mathrm{al}^{52}$ & 2008 & & & \\
\hline Ogrin et $\mathrm{al}^{45}$ & 2009 & & & $\checkmark$ \\
\hline Santos et $\mathrm{a}^{46}$ & 2009 & & & \\
\hline Count & 11 & & & 3 \\
\hline \multicolumn{5}{|l|}{ DFU } \\
\hline Baker et $\mathrm{al}^{57}$ & 1997 & $\checkmark$ & $\checkmark$ & \\
\hline Goldman et $\mathrm{al}^{58, \mathrm{~b}}$ & 2004 & & & \\
\hline Lundeberg et $\mathrm{a}^{56, \mathrm{a}}$ & 1992 & & $\checkmark$ & \\
\hline Peters et $\mathrm{a}^{55}$ & 2001 & $\checkmark$ & $\checkmark$ & \\
\hline Petrofsky et al ${ }^{54}$ & 2010 & & $\checkmark$ & \\
\hline Count & 6 & 2 & 4 & 0 \\
\hline
\end{tabular}

Notes: aStudy included both VLUs and DFU. 'btudy focused on people with critical limb ischemia - some had diabetes. ${ }^{\mathrm{C}}$ Duplicate data was included.

Abbreviations: EST, electrical stimulation therapy; DFU, diabetic foot ulcer; VLU, venous leg ulcer. 
impossible. In addition, the outcomes used to measure healing such as a reduction in wound surface or wound closure are very objective and not likely influenced by rater bias.

Lastly, many reviewers call for a single optimal treatment protocol for ESTs. This suggestion likely stems from other technologies used in wound care which are produced by the same company. The expectation that one device will be produced by industry to meet the range of needs of clinicians and patient groups is unrealistic. Admittedly, there is a variety of waveforms, electrode placements, and treatment schedules that exist in published research (Table 2). This is not entirely surprising considering that this research has been gathered over 50 years and produced by researchers across the world using equipment produced by many different manufacturers. While many parameters can be selected, it has been shown that most EST protocols produce an electrical charge within a fairly small therapeutic range $(300-700 \mu \mathrm{C} / \mathrm{s}) .{ }^{1}$ Furthermore, a recent review that evaluated different waveforms used to treat wounds showed that various forms of pulsed current can be used effectively, whereas ultralow intensities of EST have not consistently shown accelerated healing. ${ }^{94}$

Treatment schedules also vary greatly across clinical research about EST. Total treatment time calculated for each study did not suggest that there was any relationship between time EST and rate of healing produced (Table 2). Ahmad ${ }^{43}$ directly compared the effect of changing treatment times and showed that increasing treatment time from 45 to 60 minutes a session produced faster healing rates; however, further increasing treatments to 120 minutes per session did not result in any difference in healing. Thus, a maximum healing rate seems to be achieved after relatively short exposures. Any studies with longer treatment times ${ }^{44}$ do not necessarily produce faster or more complete healing. The duration of treatment (in weeks) seems to be more related to the type of wound treated with more resistant wounds (SCI, diabetes with or without ischemia) requiring longer treatments.

Evaluating the appropriateness of ESTs should be considered as part of the review of methodological quality. Most tools that assess the quality of a clinical trial examine only aspects of study design and do not address problems with EST. There are overt examples of inappropriate ESTs in this body of literature. For example, Ogrin et al only applied treatments of 5-minute duration, whereas most treatments are applied for at least 45 minutes. ${ }^{45}$ Katelaris et al combined EST with an ionic solution known for its cytotoxicity (proviodine solution). ${ }^{53}$ Apart from these two studies, there is a variety of approaches and types of electrical currents that can be used successfully to treat wounds. A benefit to this variety is that various different devices can be used and electrodes can be placed in or around the wound, and treatment schedules can be modified to fit the patient and family preferences and schedules. It provides clinicians with different ways to meet the patient's needs and potentially increases adherence to the treatment protocol. This level of customization of many features of EST does require that clinicians using it are knowledgeable about the treatment and take the necessary training to ensure that they apply it in a safe and effective manner.

\section{Summary}

Within this critical study on EST used in the treatment of chronic wounds, all relevant articles have been compiled. A list of 33 controlled clinical trials is provided which include 22 well-designed controlled clinical trials involving 1370 patients. Several case studies, prospective and retrospective cohort studies, and controlled clinical trials have been published on this topic over the past 50 years. Most of the research completed to date involve patients with pressure ulcers; however, emerging research has investigated if EST can benefit people with other types of wounds including DFUs and VLUs.

A total of $18 \mathrm{SRs}$ and/or meta-analyses have pooled studies that have evaluated the effectiveness of EST on wound healing outcomes. Conclusions derived from these reviews have been conflicting. An evaluation of methodological quality of each review and determination of the proportion of available literature that was considered in the review revealed an interesting trend. Poorer quality SRs that did not address the majority of key items set out by the PRISMA statement ${ }^{17}$ were more likely to result in inconsistent or inconclusive findings. These low-quality SRs often had very vague research questions and tried to assess the efficacy of a large number of interventions used in wound care. Having such an expansive body of literature to review resulted in retrieving a very low proportion of clinical research studies that are known to be available in the published literature.

There is clear and consistent research evidence to support the use of EST for wound healing when the results from 22 well-designed RCTs and 11 SRs with PRISMA scores above 5 are considered. Pooled results from well-constructed reviews provide strong support for the use of EST on all types of chronic wounds in general, and pressure ulcers in particular. There is only one well-designed SR that supports the use of EST on diabetic foot wounds and no good review that has compiled the research that is known to exist for EST of VLUs. 
Common recommendations for future research in this field include performing more robust clinical research that has greater sample sizes and longer treatment times so that complete wound closure is achieved. Development of single EST protocol that produces optimal treatment outcomes for types of wounds has also been recommended. However, these recommendations may not be realistic. Rather, additional research that evaluates the effect of EST on pressure ulcer may not be needed. Properly designed clinical trials with randomization, valid healing outcomes, and ITT analysis are needed to determine if EST can accelerate healing rates of diabetic foot wounds and ischemic ulcers. Well-conducted and comprehensive reviews that pool results across all the available research regarding the effects of EST on healing of VLUs are also needed.

Clinicians and wound care experts tasked with considering the research evidence as they develop clinical practice guidelines need to consider not only the results of relevant SRs and meta-analyses but also the methodological quality of these reviews. Not all SRs are created equal, and the quality and comprehensiveness of the reviews can often explain inconsistent findings and conflicting conclusions.

\section{Disclosure}

The author reports no conflicts of interest in this work.

\section{References}

1. Kloth LC. Electrical stimulation technologies for wound healing. $A d v$ Wound Care (New Rochelle). 2014;3(2):81-90.

2. Jawad H, Bain DS, Dawson H, Crawford K, Johnston A, Tucker A. The effectiveness of a novel neuromuscular electrostimulation method versus intermittent pneumatic compression in enhancing lower limb blood flow. J Vasc Surg Venous Lymphat Disord. 2014;2(2):160-165.

3. Lippert-Grüner M. Gluteal neuromuscular stimulation in therapy and prophylaxis of recurrent sacral pressure ulcers. Spinal Cord. 2003;41(6):365-366.

4. Miller C, McGuiness B, Woodward M, Boo E. Client concordance and wound healing using the BodyFlow ${ }^{\mathrm{TM}}$ electrostimulation device: case series. Wound Pract Res. 2014;22(3):145-154.

5. Liu LQ, Moody J, Traynor M, Dyson S, Gall A. A systematic review of electrical stimulation for pressure ulcer prevention and treatment in people with spinal cord injuries. J Spinal Cord Med. 2014;37(6):703-718.

6. Assimacopoulos D. Low intensity negative electric current in the treatment of ulcers of the leg due to chronic venous insufficiency. Preliminary report of three cases. Am J Surg. 1968;115(5):683-687.

7. Registered Nurses' Association of Ontario. Assessment and Management of Pressure Injuries for the Interprofessional Team. 3rd ed. Toronto, ON: Registered Nurses' Association of Ontario; 2016.

8. National Pressure Ulcer Advisory Panel; European Pressure Ulcer Advisory Panel; Pan Pacific Pressure Injury Alliance. Prevention and Treatment of Pressure Ulcers: Quick Reference Guide. Haesler E, editor. Osborne Park: Cambridge Media; 2014.

9. Qaseem A, Humphrey LL, Forciea MA, Starkey M, Denberg TD; Clinical Guidelines Committee of the American College of Physicians. Treatment of pressure ulcers: a clinical practice guideline from the American College of Physicians. Ann Intern Med. 2015;162(5): 370-379.
10. Smith ME, Totten A, Hickam DH, et al. Pressure ulcer treatment strategies: a systematic comparative effectiveness review. Ann Intern Med. 2013;159(1):39-50.

11. Houghton PE, Campbell KE; CPG Panel. Canadian Best Practice Guidelines for the Prevention and Management of Pressure Ulcers in People with Spinal Cord Injury. Mississauga, ON: Katika Integrated Communications Inc; 2013.

12. Registered Nurses' Association of Ontario. Nursing Best Practice Guidelines: Assessment and Management of Foot Ulcers for People with Diabetes. 2nd ed. Toronto, ON: Registered Nurses' Association of Ontario; 2013.

13. National Clinical Guideline Centre. Pressure ulcer management. In: The Prevention and Management of Pressure Ulcers in Primary and Secondary Care. London: National Institute for Health and Care Excellence; 2014.

14. Nicolas B, Moiziard AS, Barrois B, et al. Which medical devices and/ or local drug should be curatively used, as of 2012, for PU patients? How can granulation and epidermidalization be promoted? Developing French guidelines for clinical practice. Ann Phys Rehabil Med. 2012; 55(7):489-497.

15. Health Quality Ontario. Management of chronic pressure ulcers: an evidence-based analysis. Ont Health Technol Assess Ser. 2009;9(3):1-203.

16. Game FL, Attinger C, Hartemann A, et al. IWGDF guidance on use of interventions to enhance the healing of chronic ulcers of the foot in diabetes. Diabetes Metab Res Rev. 2016;32(Suppl 1):75-83.

17. Moher D, Liberati A, Tetzlaff J, Altman DG; PRISMA Group. Preferred reporting items for systematic reviews and meta-analyses: the PRISMA statement. PLoS Med. 2009;6(7):e1000097.

18. Sacks H, Berrier J, Reitman D, Ancona-Berk VA, Chalmers TC. Meta-analyses of randomized controlled trials. $N$ Engl $J$ Med. 1987;316(8):450-455.

19. Sackett D, Straus S, Richardson W, Rosenberg W, Haynes R. EvidenceBased Medicine: How to Practice and Teach EBM. 2nd ed. Toronto, ON: Churchill Livingstone; 2000.

20. Tricco AC, Antony J, Vafaei A, et al. Seeking effective interventions to treat complex wounds: an overview of systematic reviews. $B M C$ Med. 2015;13:89.

21. The Cochrane Library. Vol. 3. Chichester: John Wiley \& Sons Ltd; 2004.

22. Jadad AR, Moher M, Browman GP, et al. Systematic reviews and meta-analyses on treatment of asthma: critical evaluation. $B M J$. 2000;320(7234):537-540.

23. Shea BJ, Grimshaw JM, Wells GA, et al. Development of AMSTAR: a measurement tool to assess the methodological quality of systematic reviews. BMC Med Res Methodol. 2007;7:10.

24. Clark M. Technology update on electrical stimulation and wound healing. Wounds Int. 2013;4(Suppl 2):4.

25. Harding K. Electrical stimulation for wound healing needs serious consideration. Wounds Int. 2013;4(eSuppl):3.

26. Reid B, Zhao M. The electrical response to injury: molecular mechanisms and wound healing. Adv Wound Care (New Rochelle). 2014;3(2):184-201.

27. Torkaman G. Electrical stimulation of wound healing: a review of animal experimental evidence. Adv Wound Care (New Rochelle). 2014;3(2):202-218.

28. Asbjornsen G, Hernaes B, Molvaer G. The effect of transcutaneous electrical nerve stimulation on pressure sores in geriatric patients. J Clin Exp Gerontol. 1990;12(4):209-214.

29. Feedar JA, Kloth LC, Gentzkow GD. Chronic dermal ulcer healing enhanced with monophasic pulsed electrical stimulation. Phys Ther. 1991;71(9):639-649.

30. Gentzkow GD, Pollack SV, Kloth LC, Stubbs HA. Improved healing of pressure ulcers using dermapulse, a new electrical stimulation device. Wounds. 1991;3(5):158-170

31. Wood JM, Evans PE 3rd, Schallreuter KU, et al. A multicenter study on the use of pulsed low-intensity direct current for healing chronic stage II and stage III decubitus ulcers. Arch Dermatol. 1993;129(8): 999-1009. 
32. Adunsky A, Ohry A; DDCT Group. Decubitus direct current treatment (DDCT) of pressure ulcers: results of a randomized doubleblinded placebo controlled study. Arch Gerontol Geriatr. 2005;41(3): 261-269.

33. Ullah MO. A study to detect the efficacy of micro-current electrical therapy on decubitus wound. J Med Sci. 2007;7(8):1320-1324.

34. Franek A, Kostur R, Polak A, et al. Using high-voltage electrical stimulation in the treatment of recalcitrant pressure ulcers: results of a randomized, controlled clinical study. Ostomy Wound Manage. 2012;58(3):30-44.

35. Griffin JW, Tooms RE, Mendius RA, Clifft JK, Vander Zwaag R, el-Zeky F. Efficacy of high voltage pulsed current for healing of pressure ulcers in patients with spinal cord injury. Phys Ther. 1991;71(6):433-442.

36. Stefanovska A, Vodovnik L, Benko H, Turk R. Treatment of chronic wounds by means of electric and electromagnetic fields. Part 2. Value of FES parameters for pressure sore treatment. Med Biol Eng Comput. 1993;31(3):213-220.

37. Jercinovic A, Karba R, Vodovnik L, et al. Low frequency pulsed current and pressure ulcer healing. IEEE Trans Rehabil Eng. 1994;2(4):225-233.

38. Karba R, Benko H, Savrin R, Vodovnik L. Combination of occlusive dressings and electrical stimulation in pressure ulcer treatment. Med Sci Res. 1995;23:671-673.

39. Baker LL, Rubayi S, Villar F, Demuth SK. Effect of electrical stimulation waveform on healing of ulcers in human beings with spinal cord injury. Wound Repair Regen. 1996;4(1):21-28.

40. Karba R, Šemrov D, Vodovnik L, Benko H, Savrin R. DC electrical stimulation for chronic wound healing enhancement Part 1. Clinical study and determination of electrical field distribution in the numerical wound model. Bioelectrochem Bioenerg. 1997;43(2):265-270.

41. Adegoke BO, Badmos KA. Acceleration of pressure ulcer healing in spinal cord injured patients using interrupted direct current. Afr J Med Med Sci. 2001;30(3):195-197.

42. Barczak M, Kluger P, Kluger J, Bauerle J, Puhl W. Therapeutic Effectiveness of Electrical Stimulation in Paraplegic Patients with Pressure Sores [doctoral thesis]. Ulm: University of Ulm; 2001.

43. Ahmad ET. High-voltage pulsed galvanic stimulation: effect of treatment duration on healing of chronic pressure ulcers. Ann Burn Fire Disasters. 2008;21(3):124-128.

44. Houghton PE, Campbell KE, Fraser $\mathrm{CH}$, et al. Electrical stimulation therapy increases rate of healing of pressure ulcers in communitydwelling people with spinal cord injury. Arch Phys Med Rehabil. 2010;91(5):669-678.

45. Ogrin R, Darzins P, Khalil Z. The use of sensory nerve stimulation and compression bandaging to improve sensory nerve function and healing of chronic venous leg ulcers. Curr Aging Sci. 2009;2(1):72-80.

46. Santos RP, Nascimento CA, da Andrade N. Uso da eletroestimulação de alta voltagem na cicatrização de úlceras venosas [Use of high voltage electrical stimulation in healing of venous ulcers]. Fisioter Mov. 2009;22(4):615-623. Portugese [with English abstract].

47. Gogia PP, Marquez RR, Minerbo GM. Effects of high voltage galvanic stimulation on wound healing. Ostomy Wound Manage. 1992;38(1):29-35.

48. Houghton PE, Kincaid CB, Lovell M, et al. Effect of electrical stimulation on chronic leg ulcer size and appearance. Phys Ther. 2003;83(1):17-28.

49. Janković A, Binić I. Frequency rhythmic electrical modulation system in the treatment of chronic painful leg ulcers. Arch Dermatol Res. 2008;300(7):377-383.

50. Franek A, Polak A, Kucharzewski M. Modern application of high voltage stimulation for enhanced healing of venous crural ulceration. Med Eng Phys. 2000;22(9):647-655.

51. Franek A, Taradaj J, Polak A, Cierpka L, Blaszczak E. Efficacy of high voltage stimulation for healing of venous leg ulcers in surgically and conservatively treated patients. Phlebologie. 2006;35(3): $127-133$.
52. Jünger M, Arnold A, Zuder D, Stahl HW, Heising S. Local therapy and treatment costs of chronic, venous leg ulcers with electrical stimulation (Dermapulse): a prospective, placebo controlled, double blind trial. Wound Repair Regen. 2008;16(4):480-487.

53. Katelaris PM, Fletcher JP, Little JM, McEntyre RJ, Jeffcoate KW. Electrical stimulation in the treatment of chronic venous ulceration. Aust N Z J Surg. 1987;57(9):605-607.

54. Petrofsky JS, Lawson D, Berk L, Suh H. Enhanced healing of diabetic foot ulcers using local heat and electrical stimulation for $30 \mathrm{~min}$ three times per week. J Diabetes. 2010;2(1):41-46.

55. Peters EJ, Lavery LA, Armstrong DG, Fleischli JG. Electric stimulation as an adjunct to heal diabetic foot ulcers: a randomized clinical trial. Arch Phys Med Rehabil. 2001;82(6):721-725.

56. Lundeberg TC, Eriksson SV, Malm M. Electrical nerve stimulation improves healing of diabetic ulcers. Ann Plast Surg. 1992;29(4):328-331.

57. Baker LL, Chambers R, DeMuth SK, Villar F. Effects of electrical stimulation on wound healing in patients with diabetic ulcers. Diabetes Care. 1997;20(3):405-412.

58. Goldman R, Rosen M, Brewley B, Golden M. Electrotherapy promotes healing and microcirculation of infrapopliteal ischemic wounds: a prospective pilot study. Adv Skin Wound Care. 2004;17(6):284-294.

59. Carley PJ, Wainapel SF. Electrotherapy for acceleration of wound healing: low intensity direct current. Arch Phys Med Rehabil. 1985;66(7):443-446.

60. Kloth LC, Feedar JA. Acceleration of wound healing with high voltage, monophasic, pulsed current. Phys Ther. 1988;68(4):503-508.

61. Mulder GD. Treatment of open-skin wounds with electric stimulation. Arch Phys Med Rehabil. 1991;72(6):375-377.

62. Franek A, Taradaj J, Cierpka L, Blaszczak E. High voltage stimulation for healing acceleration of venous leg ulcers: usefulness after surgical treatment. Phlebologie. 2005;34(5):255-260.

63. Trontelj K, Karaba R, Vodovnik L, Savrin R, Štrukelj MP. Treatment of chronic wounds by low frequency pulsed electrical current. JTissue Viability. 1994;4(4):105-109.

64. Chalker RN. Healing of decubitus ulcers of patients in neuro-kinesthetic program with the Electro-Acuscope 80. Crit Care Update. 1983;10(3):50-52.

65. Silva Ede F, Martins CC, Guirro EC, Guirro RR. High voltage electrical stimulation as an alternative treatment for chronic ulcers of the lower limbs. An Bras Dermatol. 2010;85(4):567-569.

66. Hampton S, King L. Healing an intractable wound using bio-electrical stimulation therapy. Br J Nurs. 2005;14(15):S30-S32.

67. Hampton S, Collins F. Treating a pressure ulcer with bio-electric stimulation therapy. Br J Nurs. 2006;15(6):S14-S18.

68. Kaada B. Promoted healing of chronic ulceration by transcutaneous nerve stimulation (TNS). Vasa. 1983;12(3):262-269.

69. Lee BY, Al-Waili N, Stubbs D, et al. Ultra-low microcurrent in the management of diabetes mellitus, hypertension and chronic wounds: report of twelve cases and discussion of mechanism of action. Int J Med Sci. 2009;7(1):29-35.

70. Recio AC, Felter CE, Schneider AC, McDonald JW. High-voltage electrical stimulation for the management of stage III and IV pressure ulcers among adults with spinal cord injury: demonstration of its utility for recalcitrant wounds below the level of injury. J Spinal Cord Med. 2012;35(1):58-63.

71. Stefanovska A, Vodovnik L, Benko H, et al. Enhancement of ulcerated tissue healing by electrical stimulation. In: RESNA'87: Meeting the Challenge Proceedings of the 10th Annual Conference on Rehabilitation Technology; June 19-23, 1987; San Jose, CA.

72. Thurman BF, Christian EL. Response of a serious circulatory lesion to electrical stimulation. Phys Ther. 1971;51(10):1107-1110.

73. Allen J, Houghton PE. A case study for electrical stimulation on a stage III pressure ulcer. Wound Care Canada. 2004;2(1):34-36.

74. Moody A, Baines K. Managing a non-healing pilonidal sinus with POSiFECT e-stimulation. Br J Community Nurs. 2007;12(12):S14, S16, S18 passim. 
75. Barron JJ, Jacobson WE, Tidd G. Treatment of decubitus ulcers. A new approach. Minn Med. 1985;68(2):103-106.

76. Jacques PF, Brogan MS, Kalinowski D. High-voltage electrical treatment of refractory dermal ulcers. Physician Assist. 1997;21(3):84-100.

77. Fitzgerald GK, Newsome D. Treatment of a large infected thoracic spine wound using high voltage pulsed monophasic current. Phys Ther. 1993;73(6):355-360.

78. Cukjati D, Robnik-Sikonja M, Rebersek S, Kononenko I, Miklavcic D. Prognostic factors in the prediction of chronic wound healing by electrical stimulation. Med Biol Eng Comput. 2001;39(5):542-550.

79. Goldman R, Brewley B, Zhou L, Golden M. Electrotherapy reverses inframalleolar ischemia: a retrospective, observational study. Adv Skin Wound Care. 2003;16(2):79-89.

80. Karba R, Vodovnik L, Presern-Strukelj M, Klesnik M. Promoted healing of chronic wounds due to electrical stimulation. Wounds. 1991;3(1):16-23.

81. Karba R, Prešern-Štrukelj M, Vodovnik L, Likar B, Klešnik M. Accelerated wound healing of lower extremities by means of electrical stimulation. Adv Extern Control Hum Extremities. 1990;8:509-517.

82. Lee BY, Wendell K, Al-Waili N, Butler G. Ultra-low microcurrent therapy: a novel approach for treatment of chronic resistant wounds. Adv Ther. 2007;24(6):1202-1209.

83. Suh H, Petrofsky J, Fish A, et al. A new electrode design to improve outcomes in the treatment of chronic non-healing wounds in diabetes. Diabetes Technol Ther. 2009;11(5):315-322.

84. Debreceni L, Gyulai M, Debreceni A, Szabó K. Results of transcutaneous electrical stimulation (TES) in cure of lower extremity arterial disease. Angiology. 1995;46(7):613-618.

85. Akers TK, Gabrielson AL. The effect of high voltage galvanic stimulation on the rate of healing of decubitus ulcers. Biomed Sci Instrum. 1984;20:99-100.

86. Gault WR, Gatens PF Jr. Use of low intensity direct current in management of ischemic skin ulcers. Phys Ther. 1976;56(3):265-269.

87. Wolcott LE, Wheeler PC, Hardwicke HM, Rowley BA. Accelerated healing of skin ulcers by electrotherapy: preliminary clinical results. South Med J. 1968;62(7):795-801.

88. Goldman RJ, Brewley BI, Golden MA. Electrotherapy reoxygenates inframalleolar ischemic wounds on diabetic patients: a case series. Adv Skin Wound Care. 2002;15(3):112-120.

89. Goldman RJ, Brewley BI, Cohen R, Rudnick M. Use of electrotherapy to reverse expanding cutaneous gangrene in end-stage renal disease. Adv Skin Wound Care. 2003;16(7):363-366.

90. Burdge JJ, Hartman JF, Wright ML. A study of HVPC as an adjunctive therapy in limb salvage for chronic diabetic wounds of the lower extremity. Ostomy Wound Manage. 2009;55(8):30-38.

91. Kaada B, Emru M. Promoted healing of leprous ulcers by transcutaneous nerve stimulation. Acupunct Electrother Res. 1988;13(4): $165-176$.

92. Mulder G, Tenenhaus M, D'Souza GF. Reduction of diabetic foot ulcer healing times through use of advanced treatment modalities. Int $J$ Low Extrem Wounds. 2014;13(4):335-346.

93. Levin ME. Prevention and treatment of diabetic foot wounds. JWound Ostomy Continence Nurs. 1998;25(3):129-146.

94. Houghton PE. Clinical trials involving biphasic pulsed current, microcurrent, and/or low-intensity direct current. Adv Wound Care (New Rochelle). 2014;3(2):166-183.

95. Thakral G, LaFontaine J, Najafi B, Talal TK, Kim P, Lavery LA. Electrical stimulation to accelerate wound healing. Diabetic Foot Ankle. $2013 ; 4$.

96. Gentzkow GD. Electrical stimulation to heal dermal wounds. $J$ Dermatol Surg Oncol. 1993;19(8):753-758.

97. Sheffet A, Cytryn AS, Louria DB. Applying electric and electromagnetic energy as adjuvant treatment for pressure ulcers: a critical review. Ostomy Wound Manage. 2000;46(2):28-33, 36-40, 42-44.

98. Vodovnik L, Karba R. Treatment of chronic wounds by means of electric and electromagnetic fields: Part 1. Literature review. Med Biol Eng Comput. 1992;30(3):257-266.
99. Ojingwa J, Isseroff R. Electrical stimulation of wound healing. J Invest Dermatol. 2003;121(1):1-12.

100. Collins C, Roberts G, Zhao M, Mani R. The use of electrical stimulation of chronic wounds: a review of the evidence. $J$ Wound Technol. 2009;6:10-19.

101. Kloth LC. Electrical stimulation for wound healing: a review of evidence from in vitro studies, animal experiments, and clinical trials. Int J Low Extrem Wounds. 2005;4(1):23-44.

102. Polak A, Franek A, Taradaj J. High-voltage pulsed current electrical stimulation in wound treatment. Adv Wound Care (New Rochelle). 2014;3(2):104-117.

103. Kloth L, Zhao M. Endogenous and exogenous electrical fields for wound healing. In: McCulloch JM, Kloth L, editors. Wound Healing: Evidence-Based Management. 4th ed. Philadelphia: F.A. Davis Company; 2010:450-513.

104. Koel G, Houghton PE. Electrostimulation: current status, strength of evidence guidelines, and meta-analysis. Adv Wound Care (New Rochelle). 2014;3(2):118-126.

105. Barnes R, Shahin Y, Gohil R, Chetter I. Electrical stimulation vs. standard care for chronic ulcer healing: a systematic review and meta-analysis of randomised controlled trials. Eur J Clin Invest. 2014;44(4):429-440.

106. Cullum N, Nelson EA, Flemming K, Sheldon T. Systematic reviews of wound care management: (5) beds; (6) compression; (7) laser therapy, therapeutic ultrasound, electrotherapy and electromagnetic therapy. Health Technol Assess. 2001;5(9):1-221.

107. Kwan RL, Cheing GL, Vong SK, Lo SK. Electrophysical therapy for managing diabetic foot ulcers: a systematic review. Int Wound $J$. 2013;10(2):121-131.

108. Lala D, Spaulding SJ, Burke SM, Houghton PE. Electrical stimulation therapy for the treatment of pressure ulcers in individuals with spinal cord injury: a systematic review and meta-analysis. Int Wound J. Epub 2015 Apr 13.

109. Gardner SE, Frantz RA, Schmidt FL. Effect of electrical stimulation on chronic wound healing: a meta-analysis. Wound Repair Regen. 1999;7(6):495-503.

110. Kawasaki L, Mushahwar VK, Ho C, Dukelow SP, Chan LL, Chan KM. The mechanisms and evidence of efficacy of electrical stimulation for healing of pressure ulcer: a systematic review. Wound Repair Regen. 2014;22(2):161-173.

111. Regan MA, Teasell RW, Wolfe DL, Keast D, Mortenson WB, Aubut JA; Spinal Cord Injury Rehabilitation Evidence Research Team. A systematic review of therapeutic interventions for pressure ulcers after spinal cord injury. Arch Phys Med Rehabil. 2009;90(2):213-231.

112. Hinchliffe RJ, Valk GD, Apelqvist J, et al. A systematic review of the effectiveness of interventions to enhance the healing of chronic ulcers of the foot in diabetes. Diabetes Metab Res Rev. 2008;24(Suppl 1): S119-S144.

113. Reddy M, Gill SS, Kalkar SR, Wu W, Anderson PJ, Rochon PA. Treatment of pressure ulcers: a systematic review. JAMA. 2008; 300(22):2647-2662.

114. Reddy M. Pressure ulcers: treatment. Systematic review. BMJ Clin Evid. 2011;2010:1-43. Available from: www.ncbi.nlm.nih.gov/pmc/ articles/PMC3217823/. Accessed December 9, 2016.

115. Thakral G, La Fontaine J, Kim P, Najafi B, Nichols A, Lavery LA. Treatment options for venous leg ulcers: effectiveness of vascular surgery, bioengineered tissue, and electrical stimulation. Adv Skin Wound Care. 2015;28(4):164-172.

116. Vélez-Díaz-Pallarés M, Lozano-Montoya I, Abraha I, et al. Nonpharmacologic interventions to heal pressure ulcers in older patients: an overview of systematic reviews (The SENATOR-ONTOP series). J Am Med Dir Assoc. 2015;16(6):448-469.

117. Dickersin K. How important is publication bias? A synthesis of available data. AIDS Educ Prev. 1997;9(1 Suppl):15-21.

118. Cardinal M, Eisenbud DE, Phillips T, Harding K. Early healing rates and wound area measurements are reliable predictors of later complete wound closure. Wound Repair Regen. 2008;16(1):19-22. 


\section{Publish your work in this journal}

Chronic Wound Care Management and Research is an international, peer reviewed, open access, online journal publishing original research, reviews, editorials, and commentaries on the causes and management of chronic wounds and the major issues related to chronic wound management. Topics also include chronic wounds as comorbidities to other conditions, patient adherence to therapy, and the economic burden of chronic wounds. The manuscript management system is completely online and includes a very quick and fair peer review system, which is all easy to use. Visit http://www.dovepress.com/testimonials.php to read real quotes from published authors.

Submit your manuscript here: https://www.dovepress.com/chronic-wound-care-management-and-research-journal 